\title{
The Real Exchange Rate and Export Growth: Are Services Different?
}

\author{
Barry Eichengreen and Poonam Gupta ${ }^{1}$
}

\author{
December, 2012
}

\begin{abstract}
We consider the determinants of exports of services, distinguishing between modern and traditional services. We consider both the growth of export volumes and so-called export surges periods of rapid sustained export growth. We ask whether the determinants of export growth rates and surges differ between merchandise, traditional services and modern services and whether developing countries are different. Our findings confirm the importance of the real exchange rate for export growth. We find that the effect of the real exchange rate is even stronger for exports of services than exports of goods; it is especially strong for exports of modern services. While the evidence of differential effects between advanced and developing countries is weaker, our results nonetheless suggest that as developing countries shift from exporting primarily commodities and merchandise to exporting traditional and modern services in the course of their development, appropriate policies toward the real exchange rate become even more important.
\end{abstract}

Keywords: Real Exchange Rate, Exports, Services, Traditional Services

JEL Classification: F15; F43

\footnotetext{
${ }^{1}$ University of California, Berkeley and National Institute of Public Finance and Policy, Delhi, respectively. We thank Honey Karun for excellent research assistance. Comments are welcome at eichengr@econ.berkeley.edu and pgupta.nipfp@gmail.com.
} 


\section{Introduction}

It is fair to say that there is now a broad consensus among economists that policies encouraging exports can have a positive impact on growth. ${ }^{2}$ The marginal product of labor tends to be higher in the production of exports than other activities. Reflecting this productivity differential, export-oriented industries pay higher wages than other sectors. Exports tend to be labor intensive in developing countries, consistent with the comparative advantage implicit in factor endowments. Exports relax the balance-of-payments constraint on growth, facilitating imports of capital goods and technologies. Export industries are centers of learning by doing and sources of externalities that raise the productivity of other sectors. These and related observations have spawned a large literature concerned with the policies and circumstances conducive to export growth.

A subsidiary literature has focused specifically on the role of the real exchange rate as a determinant or facilitator of export growth (Eichengreen 2008, Rodrik 2009, Haddad and Pancaro 2010). The level of the real exchange rate is an important constituent of the relative price of exports, and relative prices matter for sectoral allocation, including the allocation of resources to the exportables sector. Real exchange rate volatility, on the other hand, can be an important complication to planning and serve as a disincentive for investment in general and for investment in capacity in the exportables sector in particular (Servén 2003).

These literatures developed in an age when trade was predominantly trade in merchandise. The new frontier today, including in developing countries, is trade in services. The exports of services have grown by about 10 percent annually worldwide between 2001 and 2010 . Since the mid-1990s, exports of services have grown by at least 15 percent annually in 20 developing countries. The share of developing countries in global trade in services rose from 14 to 21 percent between 1990 and 2008 (Goswami, Mattoo and Saez 2012). Exports of engineering, health, legal, accounting and management services, constituents of the "modern" or "non-traditional" category, have been the fastest growing component of service exports in recent years.. All this points to the question of whether the same policies and circumstances that are conducive to the growth of exports of merchandise are similarly conducive to the growth of exports of services. ${ }^{3}$

In earlier papers we considered the determinants of the size of the service sector. ${ }^{4}$ In this one we focus on service exports, distinguishing between modern and traditional services. ${ }^{5}$ Traditional services include trade and transport, tourism, financial services and insurance. Modern

\footnotetext{
${ }^{2}$ Jaleel and Kwan (1991), Feder (1982), Rodrik (2009).

${ }^{3}$ A related question, which we do not consider in this paper, is whether exports of services have the same impact on economic growth and are associated with the same spillover effects and externalities as is traditionally evidently the case of exports of merchandise.

${ }_{5}^{4}$ See Eichengreen and Gupta (2010/2011), Eichengreen (2008), Eichengreen and Gupta (2012).

${ }^{5}$ The distinction is not always straightforward in practice. One could imagine including insurance and finance in either category, for example, since exports of such services are of long standing, but their production and sale has been revolutionized by advances in information and communications technologies. In this specific case, we opt for categorizing them as traditional services, given their long history and because the export of insurance and finance is correlated highly with merchandise exports. Insurance and finance, in any case, has a small share of total services exports and its inclusion in traditional or modern services should not be of much significance. Among the individual services, travel comprises about 35 percent of service exports across countries, communication and computer-related services together account for another 35 percent, transport services account for a further 20 percent, and the remainder (about 4 percent) consist of insurance and financing.
} 
services include communications, computer, information and other related services. We consider both the growth of export volumes and so-called export surges - periods of unusually rapid sustained growth.

The focus on export growth is straightforward, but why focus also on surges? As Freund and Pierola (2012) have shown in their work on merchandise trade, surges provide additional identification. They are instances when export performance and their determinants are changing radically. They are when countries are overcoming obstacles that previously hindered export growth.

Freund and Pierola find that large sustained depreciations of the real exchange rate, implying improvements in competitiveness, typically precede surges of merchandise exports. In some of their specifications they find that low levels of exchange rate volatility and high levels of economic openness significantly predict export surges. Other variables associated with the level of exports, such as inflation and the incidence of financial crises, are not associated with surges of merchandise exports. The first question we ask in this paper is whether similar results are found for surges of service exports.

The literature points to additional variables that could be especially important for exports of services, some of which we consider in our own work. These include skills (human capital), English language facility, trade liberalisation, foreign direct investment (FDI) and the existence of an overseas diaspora. ${ }^{6}$ The role of human capital is self-evident, given the skilled-labor intensity of major tradable services. Goswami, Mattoo and Saez (2012) observe that exports of services are more information intensive than exports of merchandise; it follows that interventions limiting information asymmetries (such as regulatory requirements and measures strengthening contract enforcement) may be important in this context. Other authors have pointed to the importance of a well-developed communications infrastructure. There is an obvious link between access to the internet and modern communications on the one hand and the provision of computer and backoffice services on the other. ${ }^{7}$ Either the presence of that infrastructure or significant investments in it may thus be important for the surges we study in this paper.

There is perhaps more consensus in the literature on the effect of volatility on exports growth. Existing papers show that the volatility of exchange rates exerts a negative impact on growth, investment and on exports of goods (Servén 2003). ${ }^{8}$

Our first question is whether the determinants of export growth rates and surges differ between merchandise, traditional services and modern services. Building on the literature, we focus on the magnitude and significance of the response to the real exchange rate in particular.

\footnotetext{
${ }^{6}$ See for example Tharakan et al (2005).

${ }^{7}$ Goswami, Mattoo and Saez (2012) are skeptical that internet penetration per se is important. As they note, Malaysia has high internet penetration but is a poor performer, while India, the exceptional performer, has low internet penetration. The same may be true of telecommunications: having adequate phone lines to a few critical call centers may be more important for the Philippines than high telephonic penetration. And to the extent that inter alia telecommunications infrastructure is characterized by natural monopoly or at least network increasing returns, there may be an important role for regulation and competition policy.

${ }^{8}$ Even so, Haddad and Pancaro (2010) caution that real exchange rate volatility affects growth negatively as well the ratio of export to GDP, only at very high levels of volatility. Once the few outliers are excluded this relationship is flat.
} 
Our second question is whether developing countries are different. Eilat and Einav (2004) argue that the exchange rate matters more for exports and growth in advanced economies. In the developing-country context, in contrast, the real exchange rate is likely to matter less, while political risk is more important, for competitiveness in service sectors like tourism. In contrast, Goswami, Gupta, Mattoo and Saez (2012) find few differences in the determinants of services exports when they attempt to estimate these separately for advanced and developing economies.

Our results confirm the importance of the real exchange rate for export growth. In addition, we find that the effect of the real exchange rate is even stronger for exports of services than exports of merchandise. It is especially large for exports of modern services, as opposed to traditional varieties. The evidence for differential effects between advanced and developing countries, in contrast, is weaker. Still, this suggests that as developing countries shift from exporting primarily commodities and merchandise to exporting traditional and modern services, appropriate policies toward the real exchange rate become even more important.

The rest of our paper is organized as follows. In Section 2 we describe our data and sample. In Section 3 we present the evidence from the levels of exports. In Section 4 we define export surges in merchandise, traditional services and modern services. In Section 5 we characterize these surges. In Section 6 we present evidence on predicting the surges and the effect of RER on them. The last section concludes.

\section{Data and Sample}

Our panel covers the period 1980-2009. ${ }^{9}$ We include all countries for which significant runs of data on exports of services are available: 66 in all, of which 9 are low-income countries, 15 are low middle income, 20 are high middle income and 22 are high income. ${ }^{10}$

We organize these data into country-year observations to analyze the growth of exports of services in constant U.S. dollars. ${ }^{11}$ Table 1 shows the bivariate correlation between exports of merchandise and exports of different categories of services. While the correlation of traditional service exports and merchandise exports is relatively high, that between exports of merchandise and exports of modern services is lower. This is a first indication that the determinants of exports of modern services may be different from the determinants of surges of merchandise exports.

\footnotetext{
${ }^{9}$ Exports of services being exceptional prior to the 1980 s.

${ }^{10}$ We use the World Bank definition to classify countries into various income groups, based on the data sheet given by World Bank last updated in April 2012, by which all World Bank member economies and all other economies with populations of more than 30,000 have been classified into various income groups according to their 2010 gross national income (GNI) per capita, calculated using the World Bank Atlas method. The groups are: low income, $\$ 1,005$ or less; lower middle income, $\$ 1,006-3,975$; upper middle income, $\$ 3,976-12,275$; and high income, $\$ 12,276$ or more. For a few of our countries - Burkina Faso, Brazil, Comoros, Denmark, Hungary, Indonesia, Mozambique and Swaziland -we have data for only a portion of the period.

${ }^{11}$ More information on the sources of all data and construction of variables is in Appendix A.
} 


\section{Table 1: Correlation Coefficients between Growth of Exports of Merchandise and Different Components of Services}

\begin{tabular}{lrrrr}
\hline & Merchandise & Total Services & $\begin{array}{r}\text { Traditional } \\
\text { Services }\end{array}$ & $\begin{array}{r}\text { Modern } \\
\text { Services }\end{array}$ \\
\hline Merchandise & 1 & & & \\
Total Services & $0.39 * * *$ & 1 & & \\
Traditional Services & $0.42^{* * *}$ & $0.77 * * *$ & 1 & 1 \\
Modern Services & $0.16^{* * *}$ & $0.69 * * *$ & $0.18^{* * *}$ & \\
\hline
\end{tabular}

Note: The entry in each case is the correlation coefficient. *,**,*** indicate that the coefficient is significantly different from zero at 10,5 and 1 percent level of significance. The correlations have been calculated using the data averaged over five-year periods.

We consider four different real-exchange-rate measures. The first is the real exchange rate in purchasing-power-parity (PPP) terms, from Penn World Tables, calculated in bilateral terms visa-vis the United States (this measure is denoted "RER"). This is the RER we use to report our results but as shown in the Appendix, our results are robust to using other RER series. Second, we calculate exchange rate misalignment adjusted for the Balasa-Samuelson effect. We regress the real exchange rate in PPP terms on real per-capita GDP and calendar-year fixed effects. The extent of misalignment is then calculated as the difference between the log real exchange rate at PPP and the log fitted value from the regression (as in Cheung, Chinn and Fujii 2009 and Rodrik 2009). Third, we construct the bilateral real exchange rate vis-a-vis the United States using data from the International Monetary Fund's International Financial Statistics (IFS) on nominal exchange rates vis-a-vis the U.S. dollar and the consumer price index for the United States and other countries. Fourth and finally, we obtain an estimate of the real effective exchange rate from IFS and the World Development Indicators of the World Bank. This measure has the advantage of being multilateral rather than bilateral, but its country coverage is more limited. ${ }^{12}$

Tables A1 and A2 in Appendix A show correlations between the different exchange rate series. The correlation coefficients between different exchange rate series in levels (Table A1) are not very large, and only some of them are statistically significant. The correlations between percent changes in different real exchange rate measures (Table A2), by comparison, are quite large and also statistically significant at the 1 percent level. In particular, the correlation between the two Penn World Table-based measures, one of which adjusts for per capita incomes, is quite high (0.99), suggesting that the adjustment will make relatively little difference for what follows.

The other explanatory variables, their sources, and summary statistics are enumerated in Appendix A4 and A5.

\footnotetext{
${ }^{12}$ In addition, Rodrik (2009) tests the robustness of his results to using a bilateral Real Exchange Rate (RER) variable based on relative wholesale price indices, which we have not included for brevity.
} 


\section{The Real Exchange Rate and Export Growth}

In this section we analyze the determinants of the growth of exports of merchandise and services. We contrast traditional and modern services. We consider different measures of the real exchange rate. And we compare advanced and developing countries. We estimate different specifications and, specifically, allow the effect of RER changes to differ for depreciations and appreciations.

Our regression specification is in equation 1 in which, the dependent variable $X_{\text {it }}$ is growth rate of exports of merchandise or different categories of services for country $i$ in five-year period t. ${ }^{13}$ The independent variables include the log per capita income (over the previous five-year period), the percentage change in the real exchange rate, and the log level of the RER. We estimate these regressions using a panel of countries and five-year averages, including country and time fixed effects. ${ }^{14}$ We report standard errors that are robust as well as clustered at country level, to correct for heteroskedasticity and autocorrelation.

$$
\begin{gathered}
\mathrm{X}_{\mathrm{it}}=\alpha \log _{\text {Per Capita Income }} \text { It- }+\beta \mathrm{d} \log \text { RER }_{\mathrm{it}}+\sum_{i} \gamma_{i} \text { country fixed effects }_{\mathrm{i}}+ \\
\sum_{t} \lambda_{t} \text { period fixed effects }{ }_{\mathrm{t}}+\varepsilon_{\mathrm{it}}
\end{gathered}
$$

We subsequently extend this model by including other controls, and the interaction of these other controls with change in RER.

$$
\begin{gathered}
\mathrm{X}_{\mathrm{it}}=\alpha \log _{\text {Per Capita Income }} \text { It- } 1+\beta \mathrm{d} \log \mathrm{RER}_{\mathrm{it}}+\sum_{i} \gamma_{i} \text { country fixed effects }_{\mathrm{i}}+\sum_{t} \lambda_{t} \text { period } \\
\text { fixed effects } \\
\mathrm{t}
\end{gathered}
$$

In Table 2 the coefficient of the percentage change in the real exchange rate is positive and significant for merchandise exports, modern services, and traditional services alike. Note that the coefficient for modern services is even larger than that for traditional services. ${ }^{15}$

This larger real exchange rate effect for services, modern services in particular, reappears repeatedly in this paper; it is one of our key findings. Just why the real exchange rate impacts exports of services so powerfully is, at this point, a matter of conjecture. It could be that services, and especially modern services, use fewer imported imports. It could be that these sectors have lower fixed costs of entry, making for a more elastic supply response. It could be that demand for these exports is more price elastic. Or it could be a combination of the above. ${ }^{16}$

\footnotetext{
${ }^{13}$ We dropped outliers where export growth of merchandise, traditional or modern services exceeded 100 percent. Altogether about 20 observations were thus dropped.

${ }^{14}$ There are several benefits of estimating regressions with data averaged for five-year periods rather than with annual data. Missing observations are less of a concern. Lag structure becomes less important. Outliers are less of a concern, since we are averaging out extreme values. Finally, unit roots in real exchange rate or per capita income (for the righthand side variables) are less of an issue.

${ }^{15}$ The coefficient of log RER, in contrast, is insignificant.

16 Smith (2004) previously found that exports from different sectors respond differently to the exchange rate movement. In particular, exports of services (which include tourism) are more exchange rate sensitive than the exports of agricultural goods. He also finds that in general exports respond to exchange rate movement with a lag of 12-18 months, and that the lags with which the real exchange rate affects export volumes also differs by sector: exports of
} 
Table 2: The Real Exchange Rate and Export Growth

\begin{tabular}{lrrrrrr}
\hline & I & II & III & IV & \multicolumn{1}{c}{ V } & \multicolumn{1}{c}{ VI } \\
\hline & \multicolumn{2}{c}{ Merchandise } & \multicolumn{2}{c}{ Traditional Services } & \multicolumn{2}{c}{ Modern Services } \\
\hline Log Per Capita Income, Lag & -0.03 & -0.03 & -0.03 & -0.03 & 0.02 & 0.01 \\
& {$[1.08]$} & {$[1.02]$} & {$[1.33]$} & {$[1.43]$} & {$[0.41]$} & {$[0.28]$} \\
RER, Percent Change & $0.15^{* * *}$ & $0.14^{* * *}$ & $0.14^{* * *}$ & $0.16^{* * *}$ & $0.23^{* * *}$ & $0.26^{* * *}$ \\
& {$[4.27]$} & {$[3.18]$} & {$[4.95]$} & {$[4.75]$} & {$[3.99]$} & {$[3.87]$} \\
RER, Log & & 0.01 & & -0.03 & & -0.06 \\
& & {$[0.23]$} & & {$[1.14]$} & & {$[1.04]$} \\
\hline Country Fixed Effects & Yes & Yes & Yes & Yes & Yes & Yes \\
Time Fixed Effects & Yes & Yes & Yes & Yes & Yes & Yes \\
Observations & 380 & 380 & 380 & 380 & 380 & 380 \\
Number of countries & 66 & 66 & 66 & 66 & 66 & 66 \\
R-squared (within) & 0.15 & 0.15 & 0.17 & 0.18 & 0.13 & 0.14 \\
\hline
\end{tabular}

Note: The dependent variable is growth in exports of merchandise, traditional or modern services, (in constant USD). Observations are averages over five-year periods. Data are from 1980-2009. Regressions include country fixed effects, time fixed effect, as indicated. Standard errors are robust and clustered at countries.

In Appendix Table A3 we consider alternative measures of the real exchange rate and obtain similar results. The coefficient on the real exchange rate, however measured, is positive and significant for all different exchange rate variables, for the exports of merchandise and different services. As before, its coefficient is larger for modern services.

For the lagged exchange rate, we estimate two specifications. For the first, we include the lagged changes in real exchange rate but not also the contemporaneous value. ${ }^{17}$ In the second, we include both. As before, we estimate regressions separately for merchandise exports, exports of traditional services and modern services. Table 3 shows that when we include both the lagged and contemporaneous changes in RER, the coefficient on the contemporaneous value is positive and significant while the coefficient on the lag is insignificant. Again, the coefficient on the contemporaneous value is twice as large for modern services as for merchandise and traditional services.

services volumes respond to the real exchange rate with a lag of 18 months; manufacturing exports respond to the real exchange rate with a lag of 12-15 months, and food exports respond with about a year's lag.

${ }^{17}$ When we include only lagged changes in RER, its coefficient is insignificant. Results available on request. 
Table 3: The Real Exchange Rate, Lagged Real Exchange Rates and Export Growth

\begin{tabular}{lrrr}
\hline & I & II & III \\
\hline & Merchandise & $\begin{array}{r}\text { Traditional } \\
\text { Services }\end{array}$ & $\begin{array}{r}\text { Modern } \\
\text { Services }\end{array}$ \\
\hline Log Per Capita Income, Lag & -0.03 & -0.03 & 0.07 \\
& {$[0.96]$} & {$[0.81]$} & {$[1.26]$} \\
RER, percent change & $0.11^{* * *}$ & $0.12^{* * *}$ & $0.24 * *$ \\
& {$[3.18]$} & {$[3.97]$} & {$[4.26]$} \\
Lag RER, percent change & 0 & -0.02 & 0.01 \\
& {$[0.02]$} & {$[0.93]$} & {$[0.35]$} \\
\hline Country Fixed Effects & Yes & Yes & Yes \\
Time Fixed Effects & Yes & Yes & Yes \\
Observations & 316 & 316 & 316 \\
Number of countries & 66 & 66 & 66 \\
R-squared (within) & 0.11 & 0.19 & 0.16 \\
\hline
\end{tabular}

Notes: The dependent variables are growth in exports of merchandise (Column I), exports of traditional services (Column II) and exports of modern services (Column III), all in constant USD. Observations are averages over five-year periods. Data are from 1980-2009. Regressions include country fixed effects, and time fixed effect, as indicated. Standard errors are robust and clustered at countries.

In Table 4 we estimate regressions allowing for a differential effect of RER in developing (low and middle income) and developed (high income) countries. For this, we define a dummy which takes a value 1 for developing countries and 0 otherwise. We include the interaction of RER with this dummy variable. The results suggest that the effect of the real exchange rate on the growth of exports is broadly similar for developing countries. ${ }^{18}$ The coefficient of the interaction of RER and the dummy for developing countries is positive but insignificant. Interestingly, though the coefficient of the interaction variable is largest for modern services.

\footnotetext{
${ }^{18}$ We also interact real exchange rate variables with lag per capita income rather than with a simple dummy for developing countries in order to see if the effect of RER on growth differs incrementally with the per capita income of the countries. When we include the interaction of RER and per capita income, its coefficient is not significant, and it also takes away the significance of lag per capita income and RER (perhaps because of multicollinearity).
} 
Table: 4: RER and Growth of Exports across Countries (Different Income Groups)

\begin{tabular}{lrrr}
\hline & I & II & III \\
\hline Log Per Capita Income, Lag & Merchandise & Traditional Services & Modern Services \\
& -0.03 & -0.03 & 0.02 \\
RER, percent change & {$[1.14]$} & {$[1.41]$} & {$[0.34]$} \\
& $0.11^{* * * *}$ & $0.09 * *$ & $0.17^{* * *}$ \\
RER* developing country dummy & {$[2.80]$} & {$[2.48]$} & {$[2.90]$} \\
& 0.04 & 0.06 & 0.07 \\
Constant & {$[0.73]$} & {$[1.54]$} & {$[0.97]$} \\
& 0.3 & 0.34 & -0.05 \\
Country Fixed Effects & {$[1.37]$} & {$[1.65]$} & {$[0.11]$} \\
Time Fixed Effects & Yes & Yes & Yes \\
Observations & Yes & Yes & Yes \\
Number of Countries & 380 & 380 & 380 \\
R-squared (within) & 66 & 66 & 66 \\
& 0.15 & 0.18 & 0.13 \\
\hline
\end{tabular}

Note: The dependent variables are growth in exports of merchandise (Column I), exports of traditional services (Column II) and exports of modern services (Column III), all in constant USD. Observations are averages over fiveyear periods. Data are from 1980-2009. Regressions include country fixed effects, time fixed effect, as indicated.

Standard errors are robust and clustered at countries.

Next we define a dummy variable that equals 1 when the percentage change in the real exchange rate is positive, i.e. when there is a depreciation, and 0 when the percent change in real exchange rate is 0 or negative, i.e. when there is no change or an appreciation, interacting the dummy with the real exchange rate. Results are in Table 5. For merchandise exports, the effect of exchange rate depreciation is somewhat larger but does not differ significantly from the effect of appreciation. Nevertheless, the coefficient of RER for depreciation $(0.07+0.12)$ is significantly different from 0 at 1 percent level of significance. For exports of traditional and modern services, an appreciation does not seem to affect export growth, but the effect of depreciation is positive, large and significant. As before, the effect is larger for export of modern services than for traditional services. 
Table 5: Depreciation vs. Appreciation and Export Growth

\begin{tabular}{lrrr}
\hline & I & III & V \\
\hline & Merchandise & $\begin{array}{c}\text { Traditional } \\
\text { Services }\end{array}$ & $\begin{array}{c}\text { Modern } \\
\text { Services }\end{array}$ \\
\hline Log Per Capita Income, & -0.03 & -0.03 & 0.02 \\
Lag & {$[1.09]$} & {$[1.38]$} & {$[0.35]$} \\
RER, percent change & 0.07 & 0.05 & 0.05 \\
& {$[0.94]$} & {$[0.95]$} & {$[0.75]$} \\
RER* depreciation & 0.12 & & $0.28^{* *}$ \\
dummy & & $0.15^{* *}$ & \\
& {$[1.19]$} & {$[2.02]$} & {$[2.28]$} \\
\hline Country Fixed Effects & Yes & Yes & Yes \\
Time Fixed Effects & Yes & Yes & Yes \\
Observations & 380 & 380 & 380 \\
Number of countries & 66 & 66 & 66 \\
R-squared & 0.15 & 0.18 & 0.14 \\
\hline
\end{tabular}

Note: The dependent variables are growth in exports of merchandise, exports of traditional services, and exports of modern services, all in constant USD. Observations are averages over five-year periods. Data are from 1980-2009. Regressions include country fixed effects, time fixed effect, as indicated. Standard errors are robust and clustered at countries.

In sum, we find that real exchange rate changes affect exports of merchandise and traditional services in broadly similar ways, but that the effect on modern services is 30 to 50 percent larger.

To probe robustness, we add a vector of controls in the regression specification in equation 2, including savings rates, FDI (net FDI, as a share of GDP), an indicator for English-speaking population, a dummy for currency crises, years since a country joined the World Trade Organization, a measure of internet penetration, tariff rate and a financial reform index. Table B1 shows the summary statistics for these variables. We include them by themselves and, in addition, interact them with the real exchange rate. Because some of these variables are time invariant or move slowly, such as the dummy for English-speaking population, when we include these variables we estimate the specifications with random effects.

When these additional variables are included in the regressions, one at a time, only some of them enter significantly. When we include interaction of the other controls with RER in the regressions, the coefficients of these interaction terms are insignificant, indicating that the effect of RER on exports growth is not conditional on these factors. More details and associated sensitivity analysis can be found in Appendix B. But, importantly, the coefficient on the real exchange rate remains large and significant, as before. Again, as before, the effect of the real exchange rate is larger for 
modern services (Tables B1-B3). ${ }^{19}$ For a summary of regression results with the inclusion of other controls, see Table 6.

\section{Table 6: Summary of Regression Results with Other Controls ${ }^{20}$}

\begin{tabular}{llll}
\hline & Merchandise & Traditional Services & Modern Services \\
\hline $\begin{array}{l}\text { One variable } \\
\text { at a time }\end{array}$ & $\begin{array}{l}\text { RER, Crises: have } \\
\text { positive and } \\
\text { significant } \\
\text { coefficients }\end{array}$ & $\begin{array}{l}\text { RER, FDI, crises: have } \\
\text { positive and significant } \\
\text { coefficients }\end{array}$ & $\begin{array}{l}\text { RER, English, crises, FDI: } \\
\text { all have positive and } \\
\text { significant coefficients }\end{array}$ \\
\hline $\begin{array}{l}\text { Including } \\
\text { several } \\
\text { variables } \\
\text { together }\end{array}$ & $\begin{array}{l}\text { RER has a positive } \\
\text { and significant } \\
\text { coefficient }\end{array}$ & $\begin{array}{l}\text { RER, FDI, crises: have } \\
\text { positive and significant } \\
\text { coefficients }\end{array}$ & $\begin{array}{l}\text { RER has a positive and } \\
\text { significant coefficient }\end{array}$ \\
\hline
\end{tabular}

\section{Surges}

We now use the Bai-Perron structural break technique to identify surges in exports of merchandise, modern services and traditional services. ${ }^{21}$ We define a surge when a pair of breaks points to first a significant acceleration and then a significant deceleration of exports. In addition, we require the export growth rate to be at least 2 percent a year for three consecutive years. So defined, the surge lasts until the growth rate falls below 2 percent or until another structural break is identified. ${ }^{22}$ In Appendix C, Figure C1, we show the surges thus identified for India.

\footnotetext{
19 In addition to the results in the Appendix, we included several other variables in the regressions but have not reported the results. These include a financial reform index; domestic credit/GDP, both as measures of financial sector development; distance from major financial centers; internet penetration; education. The coefficients of these variables are insignificant in all cases. The insignificant coefficient of education variable for modern services is a bit surprising. We tested the robustness of this result in a number of ways. We looked for outliers: India seemed to be somewhat of an outlier with a low average schooling and a high growth of export of modern services. However dropping India does not make all that much difference to the coefficient of the variable. We also tried three different education attainment variables available from the Barro and Lee dataset: average years of schooling in population more than 15 years of age; percent of population with completed tertiary educations in 25-plus age group; percent of population with secondary education competed in 25-plus age group. Recognizing the fact that education is a slow-moving variable even in five-year averages, we estimate regressions with random effects, or just OLS so as to combine between and within countries variation, rather than just within country variation. In the end, the results do not change much.

${ }^{20}$ Volatility of nominal exchange rate has a positive and significant coefficient for traditional services; savings and tariff are not significant in any of the regressions; WTO dummy is positive in all regressions and is significant for traditional and modern services. The coefficient of currency crisis is positive and significant, which is a bit surprising perhaps. However as Gupta, Mishra and Sahay (2007) have shown, crises may not be detrimental to growth in developing countries and indeed if the countries have low external debt, may be associated with faster exports growth. ${ }^{21}$ Bai and Perron (2003) derive the rate of convergence and the limiting distributions of the estimated break points. The results are obtained under a general framework of partial structural changes, which allows a subset of the parameters not to change (and, of course, includes a pure structural change model as a special case). They also address the important problem of testing for multiple structural changes: a sup Wald type tests for the null hypothesis of no change versus an alternative containing an arbitrary number of changes and a procedure that allows one to test the null hypothesis of, say, 1 change, versus the alternative hypothesis of $1+1$ changes.

${ }^{22}$ We do consider whether the second point can be considered as a continuation of the same export surge by meeting the same criteria that we have used.
} 
We identified 81 episodes of surges in the exports of merchandise, 100 episodes of surges of traditional services and 80 episodes of surges in exports of modern services. Table 7 shows the distribution of durations of surges. Typically surges in all categories of exports last four to five years. There are a large number of surges in traditional services that last only three years. ${ }^{23}$

\section{Table 7: Duration of Surges in Exports of Merchandise and Traditional and Modern Services}

\begin{tabular}{lccc}
\hline $\begin{array}{l}\text { Duration of } \\
\text { Surge (Years) }\end{array}$ & $\begin{array}{c}\text { Number of Surges: } \\
\text { Merchandise }\end{array}$ & $\begin{array}{c}\text { Number of Surges: } \\
\text { Traditional Services }\end{array}$ & $\begin{array}{c}\text { Number of Surges: } \\
\text { Modern Services }\end{array}$ \\
\hline 3 & 3 & 33 & 0 \\
4 & 34 & 32 & 38 \\
5 & 19 & 19 & 17 \\
6 & 9 & 4 & 6 \\
7 & 8 & 7 & 11 \\
8 & 6 & 3 & 5 \\
9 or more & 2 & 2 & 3 \\
\hline Average & 5.1 & 4.4 & 5.2 \\
Duration & & & \\
\hline
\end{tabular}

In Table 8 we consider the average growth rate of exports before, during and after the surge episodes. The average growth rate of merchandise exports is about 15 percent per annum during surges. In the year before the surge it is 0.4 percent, and it turns negative after the surge. The pattern of growth of exports of traditional services during surge episodes is quite similar to that of merchandise exports. Surges in exports of modern services are most pronounced, with the exports of modern services growing at roughly 25 percent per annum during the surge period. In the years before the surge, in contrast, the growth of modern service exports is less than 3 percent, and it turns negative after the surge. Exports of modern services do not grow faster in the three years following the surge than they did in the three years before it. Evidently, increases in exports of modern services begin suddenly, last about 5 years, and it is often difficult to build on the momentum they create.

\footnotetext{
${ }^{23}$ As a robustness check we drop these shorter surges; doing so makes little difference for the results.
} 
Table 8: Export Growth during Surges

\begin{tabular}{|c|c|c|c|c|c|c|}
\hline & $\begin{array}{c}\text { During } \\
\text { the year } \\
\text { export } \\
\text { surge } \\
\text { starts }\end{array}$ & $\begin{array}{l}\text { During the } \\
\text { entire } \\
\text { duration of } \\
\text { the surge }\end{array}$ & $\begin{array}{l}\text { One } \\
\text { year } \\
\text { prior } \\
\text { to } \\
\text { surge }\end{array}$ & $\begin{array}{l}\text { Three } \\
\text { years } \\
\text { prior to } \\
\text { surge }\end{array}$ & $\begin{array}{l}\text { One } \\
\text { year } \\
\text { after } \\
\text { the } \\
\text { surge }\end{array}$ & $\begin{array}{l}\text { Three } \\
\text { years } \\
\text { after } \\
\text { the } \\
\text { surge }\end{array}$ \\
\hline & \multicolumn{6}{|c|}{ Surges in Exports of Merchandise } \\
\hline \multirow[t]{2}{*}{ Export Growth of Merchandise } & 15.3 & 13.7 & -0.2 & 0.3 & -4.7 & 3.2 \\
\hline & \multicolumn{6}{|c|}{ Surges in Exports of Traditional Services } \\
\hline \multirow[t]{2}{*}{ Export Growth of Traditional Services } & 15.1 & 14.8 & 4.1 & 1.5 & -6.4 & -0.2 \\
\hline & \multicolumn{6}{|c|}{ Surges in Exports of Modern Services } \\
\hline Export Growth of Modern Services & 28.2 & 25.5 & 2.8 & 2.3 & -7.7 & 0.53 \\
\hline
\end{tabular}

In Figure 2, we look at the growth rates around the surge periods, where time 0 is the years of the surge, while the negative values refer to the years immediately before it and positive values to the years immediately after. The visual depiction reinforces the picture painted by Table 8 .

Figure 2a: Average Growth Rate of Exports of Merchandise Exports Before, During and After the Surge

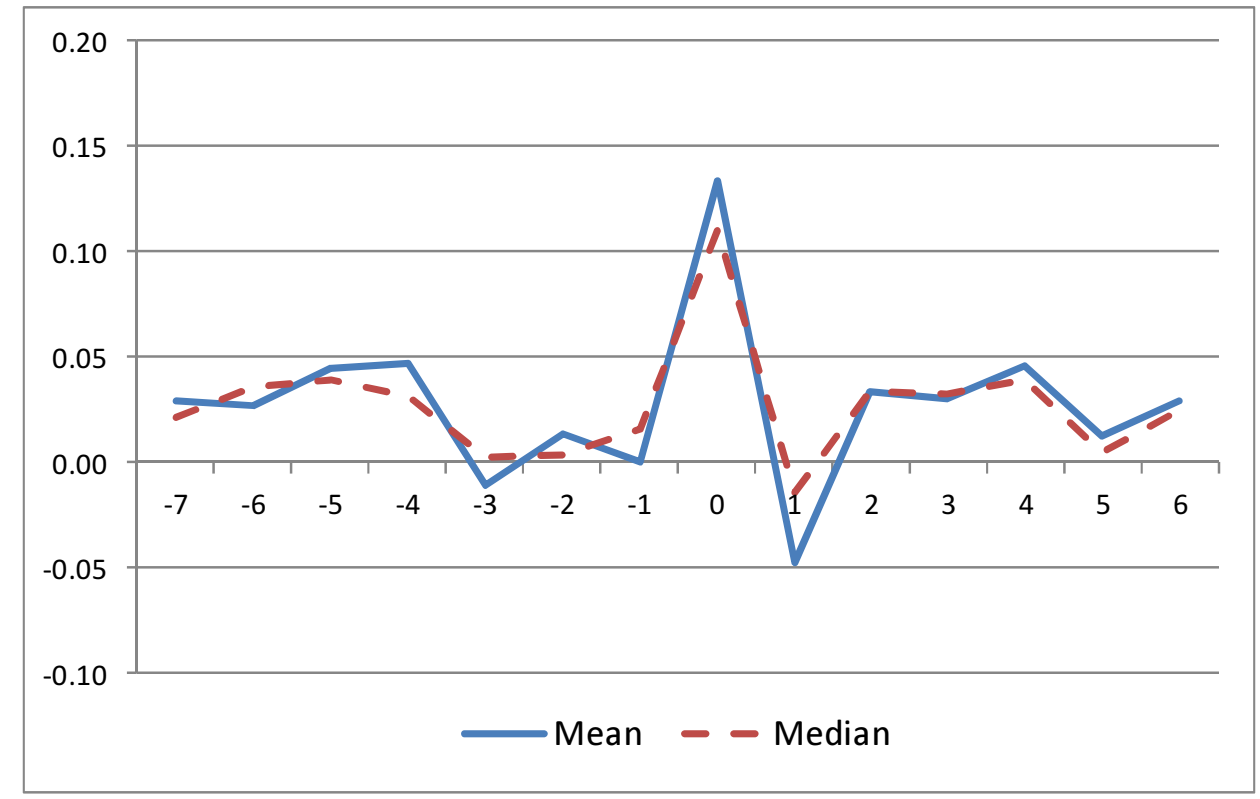


Figure 2b: Average Growth Rate of Exports of Traditional Services Before, During and After the Export Surge

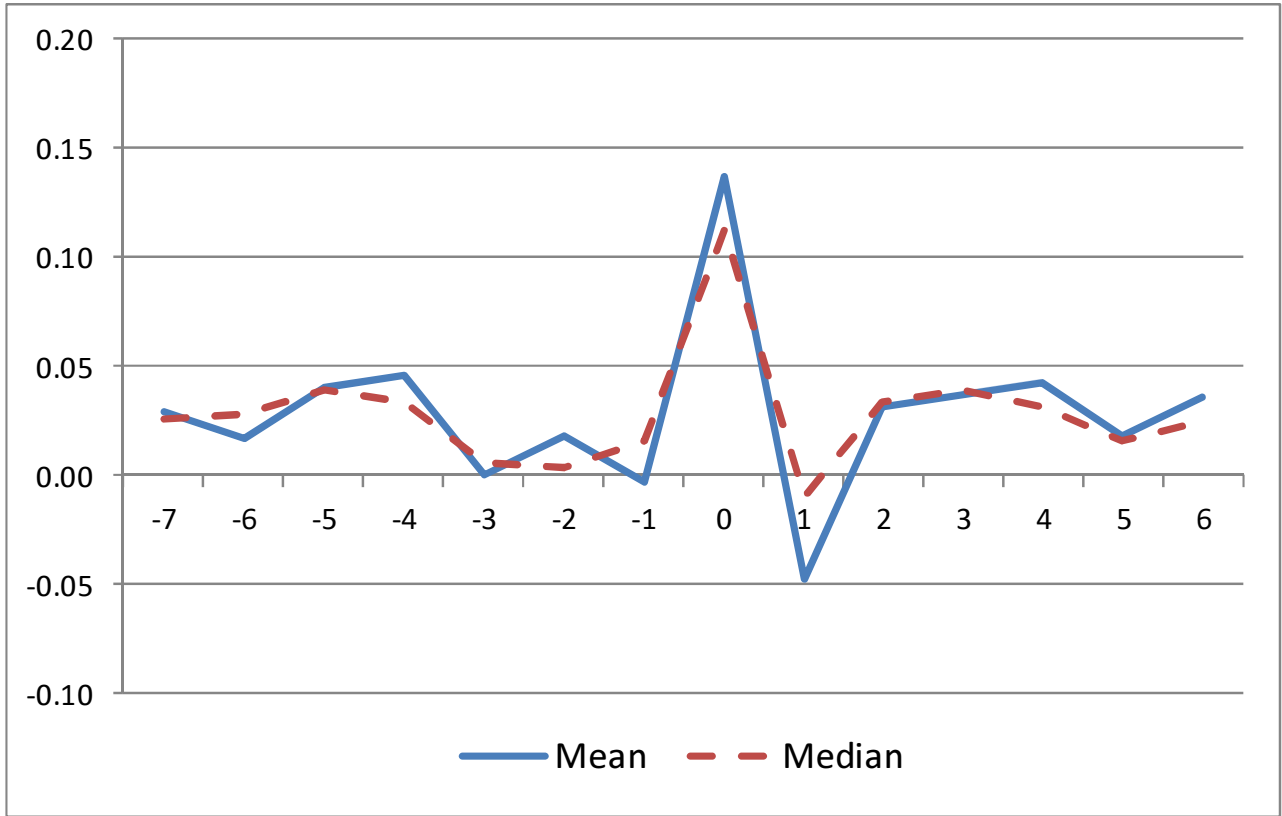

Figure 2c: Average Growth Rate of Exports of Modern Services Before, During and After the Export Surges

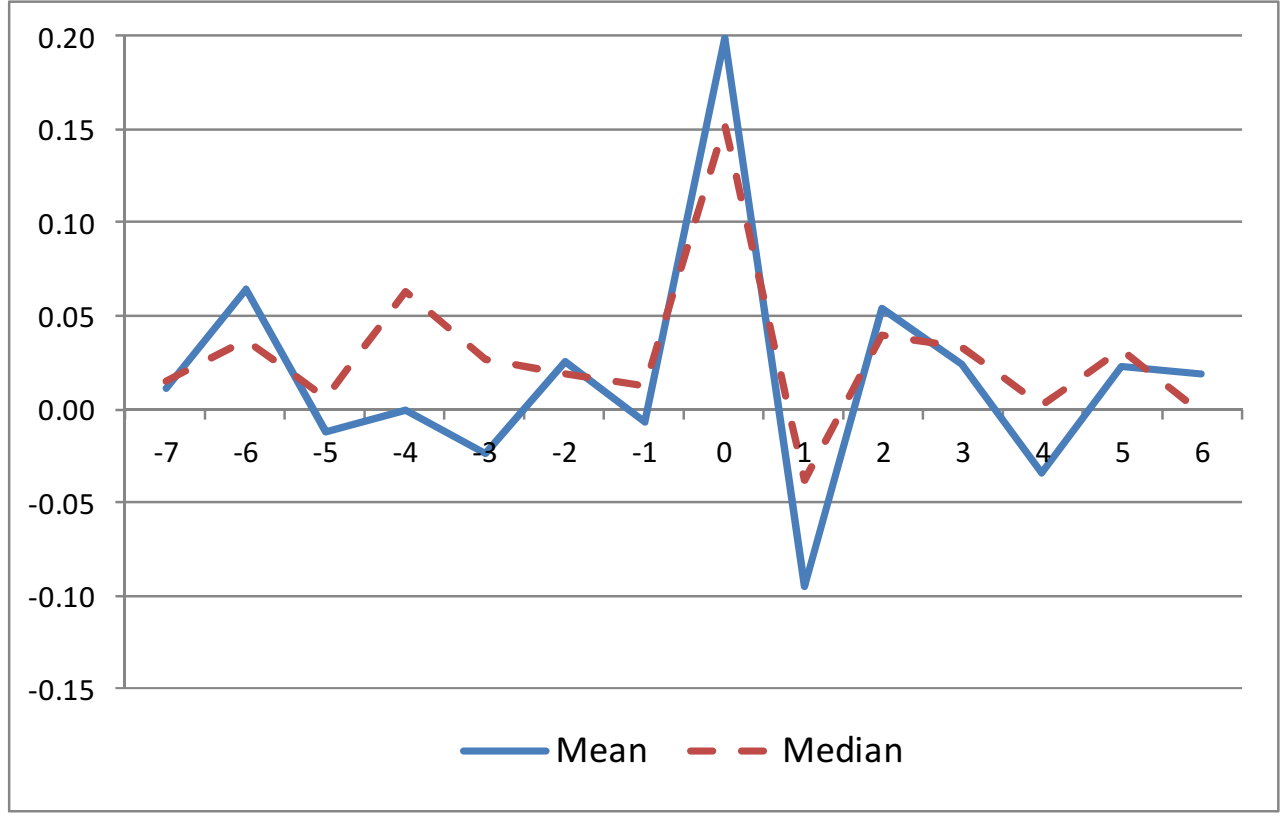

The time distribution of surges is shown in Appendix E, Figures E1-E3. Compared to surges in exports of merchandise, surges of exports of modern services appear to be somewhat 
more evenly distributed over time. For merchandise there seems to be a concentration of episodes in the early 1990s and in early the 2000s, reflecting the widespread adoption of outward-oriented reforms and increases in production fragmentation and global supply chains. It might be thought that surges in exports of services reflect the diffusion of modern information and communications technology and similarly would be concentrated in this recent period. Interestingly, we do not find this to be the case. For traditional services, the clusters of surges are in 1985, 1986, 1994 and 2004. For modern services, there are clusters of surges in 1996, 1998 and 2004-2005.

\section{Characterizing Export Surges}

Following Fruend and Pierola, we examine the behavior of the RER, its volatility, FDI, saving, tariff rates, financial reforms and internet penetration around the surge episodes. We examine them separately for traditional and modern services as well as for developing and developed countries. Figure 3 shows that surges in exports of services, both modern and traditional, tend to be preceded by real exchange rate depreciations, especially in developing countries. On the other hand, export surges do not seem to be preceded by declining RER volatility (see Figure 4).

Figure 3: RER and Export Surges in Traditional and Modern Services

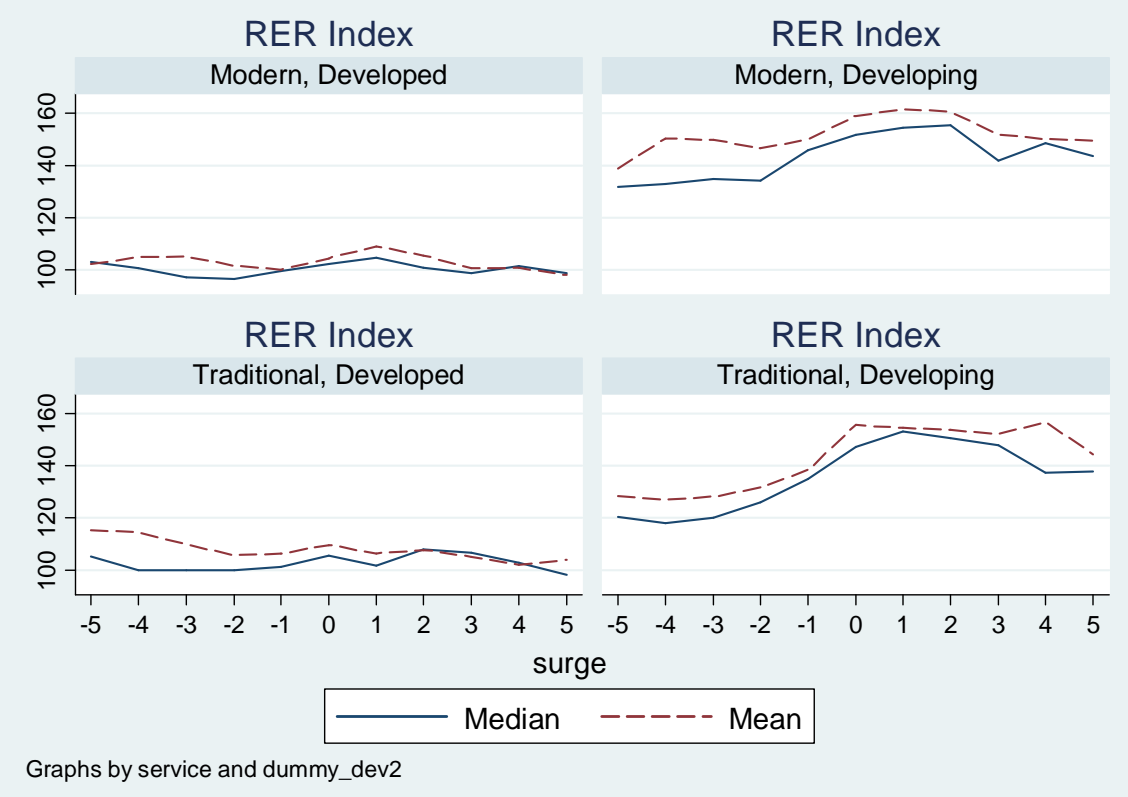


Figure 4: RER Volatility and Surges in Exports of Traditional and Modern Services

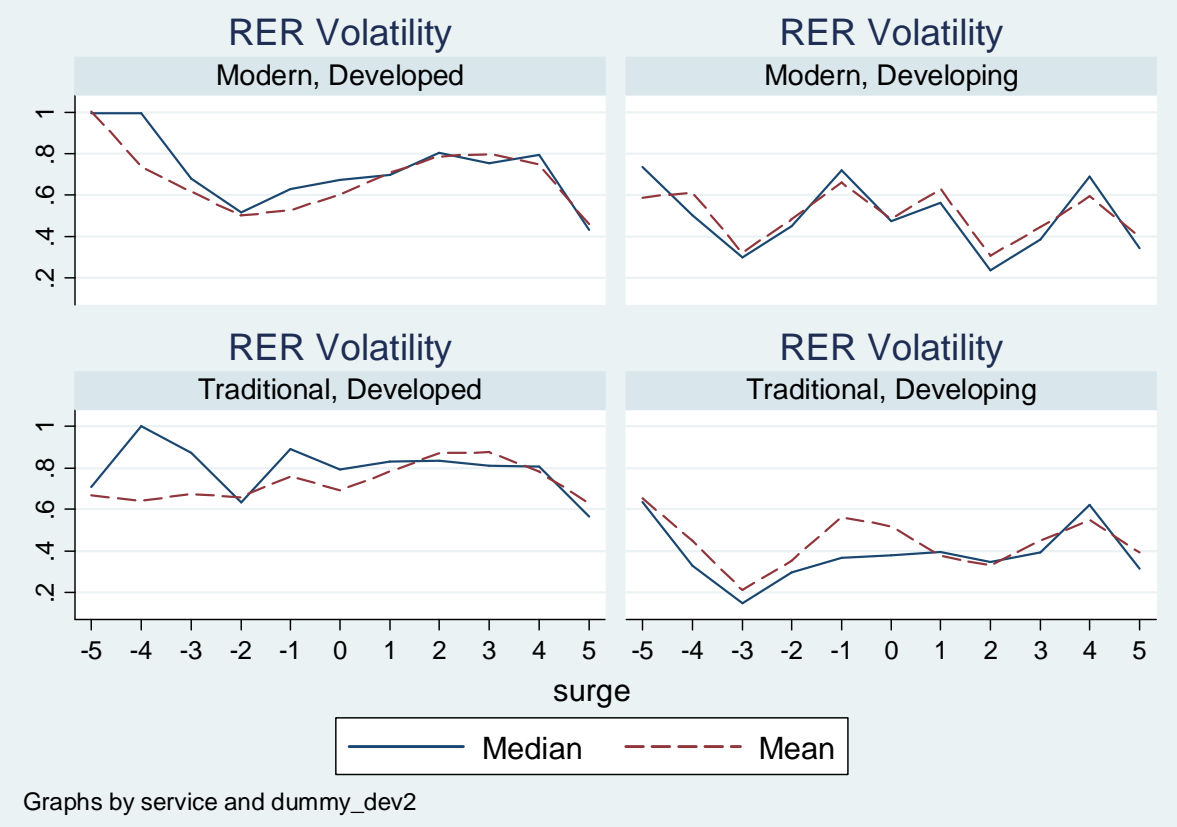

On import tariffs we see some mild decline in the level of tariffs prior to surges in service exports (Figure 5).

Figure 5: Import Tariffs and Surges in Exports of Traditional and Modern Services

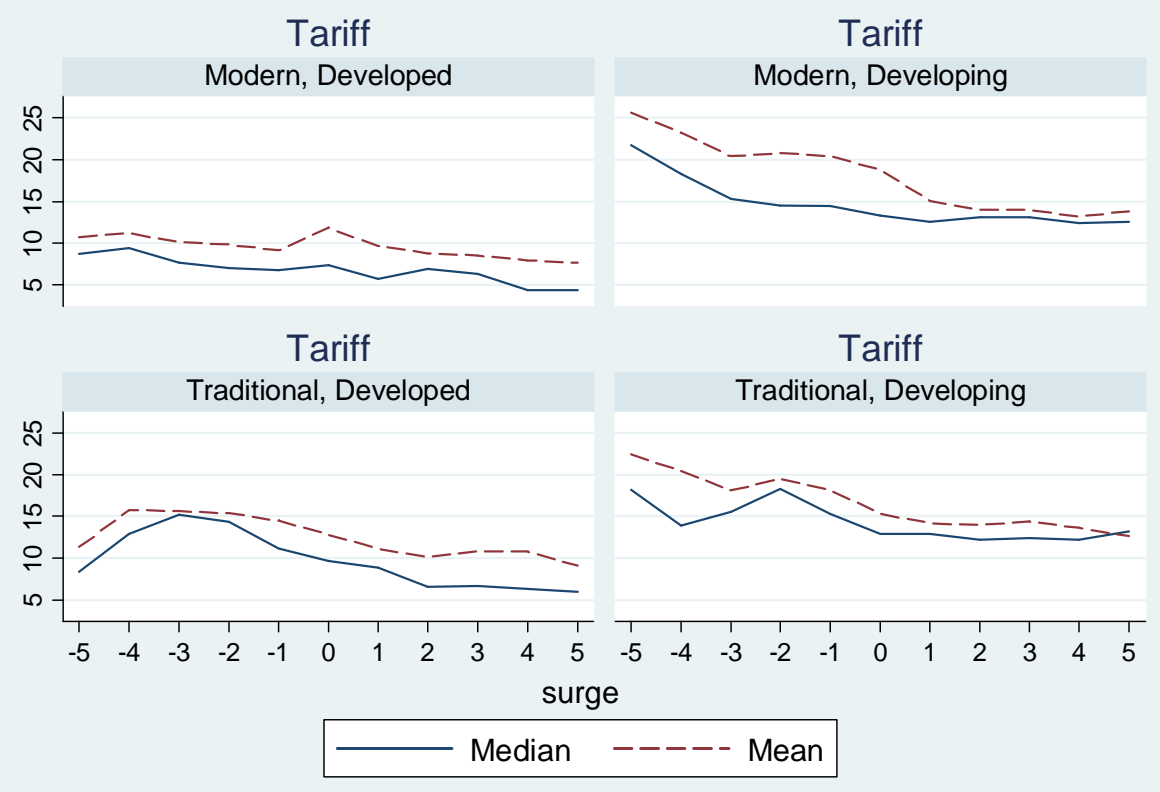

Graphs by service and dummy_dev2 
Surges in service exports also seem to be preceded by increases in FDI inflows and in the savings rate, especially in developing countries (Figure 6).

Figure 6: FDI and Surges in Exports of Traditional and Modern Services

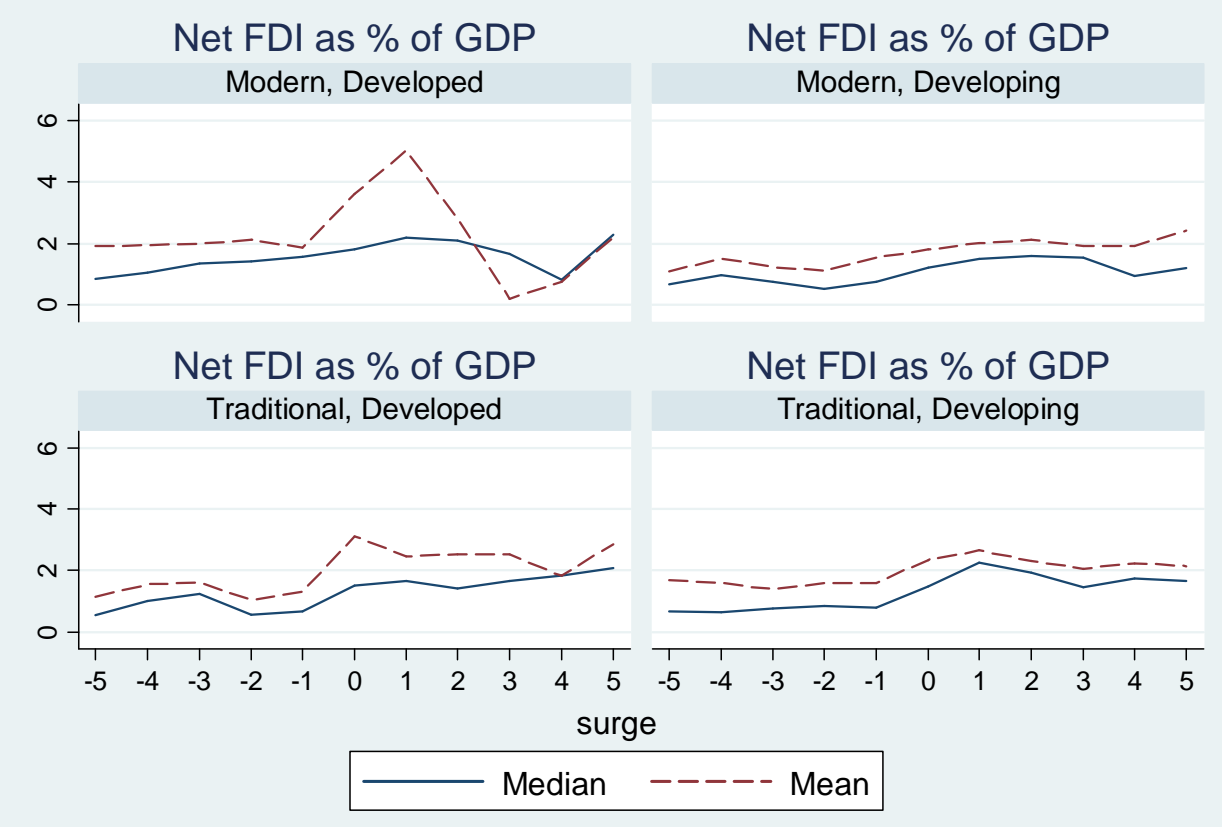

Graphs by service and dummy_dev2

We show the behavior of more variables in Appendix E, Figures E1-E3. The financial reform index in Figure E1 shows a trend toward liberalization of the financial sector prior to the surges of exports of services, and especially fast liberalization prior to the surge in the exports of modern services by developing countries. Export surges also seem to be preceded by an increase in the saving rate, especially in developing countries (Figure E2). Surges in exports of modern services, especially in developed countries, are accompanied by and preceded by a sharp increase in the internet penetration (Figure E3). 
Figure 7: Surges in Exports of Traditional and Modern Services and Per Capita Income

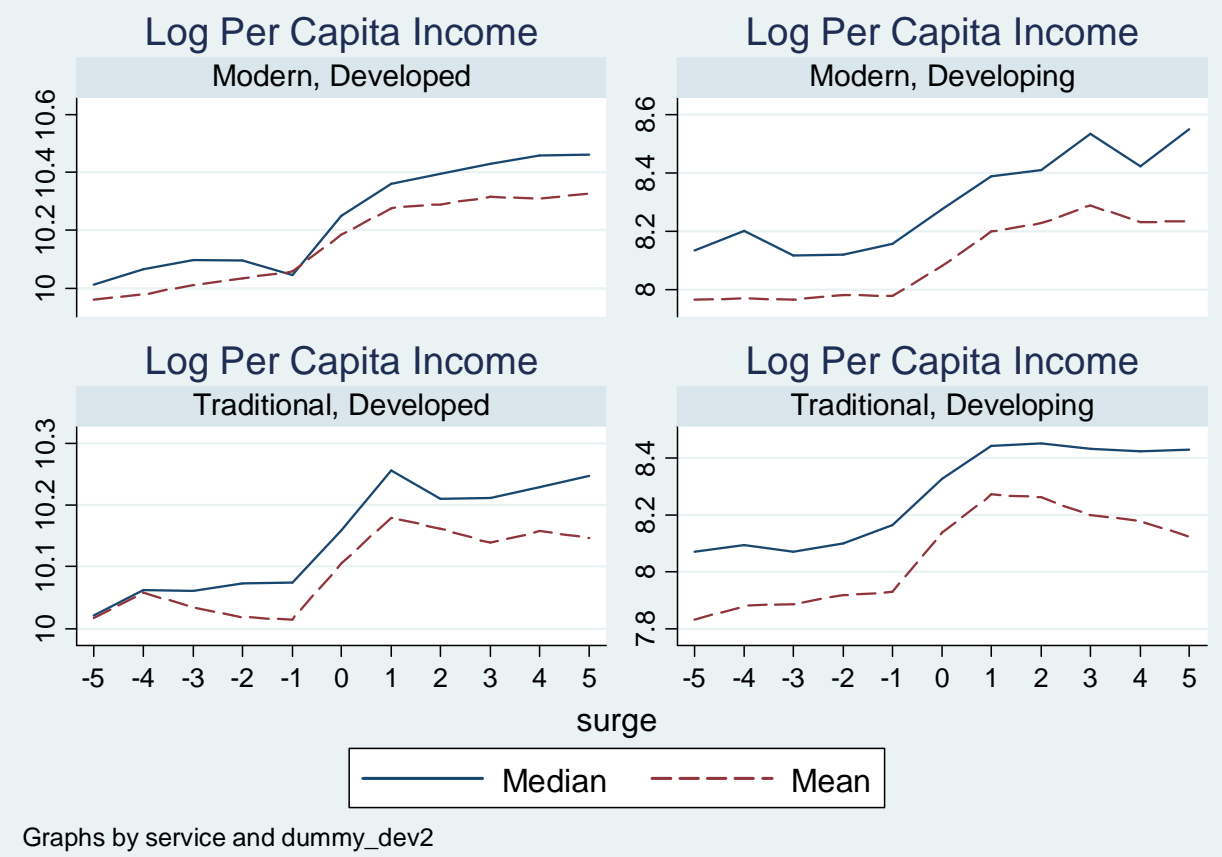

Even though we do not look at the effects of export surges in this paper, Figure 7 shows a remarkable acceleration in per capita income growth during an export surge in services. The acceleration is short lived in traditional services surges, but lasts longer for surges in modern services.

\section{The Real Exchange Rate and Export Surges}

We estimate regressions of the determinants of the timing of a surge in the exports of merchandise, traditional and modern services, focusing again on the real exchange rate. For the dependent variable, we create a dummy which takes a value 1 for all the years of that exports surge and 0 otherwise. We regress it on log per capita income and RER (the average of previous three years to smooth out noise in annual data). As before, as controls (again averages of three previous years) we include volatility of the real exchange rate, the savings rate, FDI, an indicator of an English-speaking population, a dummy for currency crises and the tariff rate. ${ }^{24} \mathrm{We}$ include year fixed effects to account for global events affecting the exports.

\footnotetext{
${ }^{24}$ We also included years since a country joined the World Trade Organization, a financial reform index and internet penetration in the regression, but their coefficients are uniformly insignificant. There seems to be a general trend toward trade liberalisation and financial sector liberalisation in all countries, which is not noticeably stronger before the surges. The insignificant coefficients are perhaps reflecting these general trends. The results on trade reform are consistent with Freund and Pierola. The authors provide rationale for this result, namely that trade reforms are often sector specific and hence may not influence the overall exports growth.
} 
The approach we have used here is similar to the one used by Hausmann, Pritchett, and Rodrik (2005) who defined growth acceleration, using an algorithm, to pick up turning points in growth performance. Working with 80 such episodes of growth acceleration, they analyze their determinants by estimating a probit model on the dummy for accelerations. They find that the overall predictive power of the model is low, but nevertheless growth accelerations are correlated with RER depreciation, investment, trade openness and economic reforms.

Table 9: Real Exchange Rate and Export Surges

\begin{tabular}{lrrrrrr}
\hline & I & II & III & IV & V & VI \\
\hline & \multicolumn{1}{c}{ Merchandise } & \multicolumn{2}{c}{ Traditional } \\
Services
\end{tabular}

Note: $*, * *, * *$ indicate that coefficients are significant at 10, 5, 1 percent levels respectively. All regressions include robust standard errors. All regressions are estimated by probit and marginal effects are reported.

Consistent with our earlier analysis, RER depreciation has a positive and significant effect on the probability of a surge of both merchandise and services, as shown in Table 9. Now, however, it would appear that the effect is slightly larger for goods and traditional services. We interact RER with the dummy for developing countries to see if RER has a different effect on the probability of an export surge. The coefficient of this interaction variable is not significantly different from zero. We try several variations, some of which we present in Appendix E, Tables E1-E3, but the results are broadly robust. To establish robustness we also estimate a random effect probit model, a linear probability model with country fixed effects and year fixed effects, and a random effects logit model. We calculate robust standard errors and, alternatively, cluster standard errors by country. Since traditional services have many surge episodes which last only three years, we also test the robustness of the results to dropping the episodes lasting three years.

Next we include other controls in the regressions (Table 10). As before, in all the columns we estimate probit models and report marginal effects. As is evident from the table, including other controls does not make much of a difference to the results, and RER continues to have a positive and significant coefficient. Results also show that the volatility of RER has a negative effect on the probability of an export surge, consistent with Freund and Pierola (2012). Experiencing a currency crisis in the recent past does not affect the probability one way or the other but its effect is positive and marginally significant for the export surge in traditional services. This finding is somewhat consistent with the pattern observed by Borchert and Mattoo (2009). It also seems to be a 
promising area for future research. An English-speaking population increases the probability of an export surge in modern services, which is intuitive. Higher FDI inflows and a higher savings rate are associated with a greater likelihood of a surge of exports of traditional services and merchandise. $^{25}$

To explore the robustness of these results, we estimate Tobit regressions in which the dependent variable equals the growth of the exports of the corresponding series if there is a surge and zero if there is no surge. These results make fuller use of the data, in the sense of distinguishing larger and smaller surges, and as such should be more informative than those in Tables 9 and 10. Again, we include year fixed effects and cluster standard errors by countries. We estimate these regressions including the RER and per capita income, and with the interaction of the RER with the dummy for developing countries, with and without additional controls (compare Tables 11 and 12). We now find, as above, a larger impact of the real exchange rate on exports of modern services than on traditional services and on traditional services than on merchandise (as before, the coefficient of RER is about 50 percent larger for modern services).

Among other variables with significant coefficients, as in the probit regressions, RER volatility has negative coefficients; currency crises, English-speaking population, FDI etc. all have coefficients similar to the ones obtained in probit regressions. Again, there is no indication of significant differences between advanced and industrial countries.

\footnotetext{
${ }^{25}$ We estimate several more specifications, especially by including these "other controls" one at a time. The results are in Appendix E, Tables E4-E6. In all the specifications RER continues to have a large, positive effect on the probability of an export surge.
} 
Table 10: RER, Other Controls and Export Surges

\begin{tabular}{lcccccc}
\hline & I & II & III & IV & V & VI \\
\cline { 2 - 7 } & \multicolumn{2}{c}{ Merchandise } & \multicolumn{2}{c}{ Traditional Services } & \multicolumn{2}{c}{ Modern Services } \\
\hline RER, Average & $0.79 * * *$ & $0.79 * * *$ & $1.07 * * *$ & $1.07 * * *$ & $0.75^{* * *}$ & $0.75^{* *}$ \\
& {$[4.19]$} & {$[2.93]$} & {$[5.80]$} & {$[4.24]$} & {$[3.95]$} & {$[2.44]$} \\
Log Per Capita Income, PPP, & 0.01 & 0.01 & -0.02 & -0.02 & $0.04 * * *$ & $0.04 *$ \\
Lag & & & & & & \\
& {$[0.83]$} & {$[0.42]$} & {$[1.41]$} & {$[0.88]$} & {$[3.16]$} & {$[1.93]$} \\
RER Volatility, Average & $-0.06^{* * *}$ & $-0.06^{*}$ & $-0.09 * * *$ & $-0.09 * * *$ & $-0.06 * * *$ & $-0.06^{* *}$ \\
& {$[3.20]$} & {$[1.73]$} & {$[4.57]$} & {$[2.68]$} & {$[3.52]$} & {$[2.11]$} \\
Currency Crisis, Lag & 0.02 & 0.02 & $0.10 *$ & $0.10 *$ & 0.02 & 0.02 \\
& {$[0.40]$} & {$[0.41]$} & {$[1.81]$} & {$[1.81]$} & {$[0.28]$} & {$[0.37]$} \\
FDI, Average & $0.01 *$ & 0.01 & $0.02 * * *$ & $0.02 * *$ & 0 & 0 \\
& {$[1.85]$} & {$[1.14]$} & {$[3.67]$} & {$[2.31]$} & {$[0.22]$} & {$[0.13]$} \\
Savings, Average & $0.00 * *$ & 0 & $0.01 * * *$ & $0.01 * * *$ & 0 & 0 \\
& {$[2.53]$} & {$[1.47]$} & {$[4.37]$} & {$[2.58]$} & {$[1.58]$} & {$[1.15]$} \\
Index, English & 0.01 & 0.01 & 0.01 & 0.01 & $0.02 * *$ & 0.02 \\
& {$[0.56]$} & {$[0.29]$} & {$[0.81]$} & {$[0.41]$} & {$[2.30]$} & {$[1.33]$} \\
\hline Year Fixed Effects & Yes & Yes & Yes & Yes & Yes & Yes \\
Number of Observations & 1412 & 1412 & 1417 & 1417 & 1398 & 1398 \\
Pseudo R- squared & 0.11 & 0.11 & 0.12 & 0.12 & 0.06 & 0.06 \\
\hline
\end{tabular}

Note: *,**,*** indicate that coefficients are significant at 10, 5, 1 percent levels respectively.In Column I, III and V standard errors are robust; whereas in Columns II, IV and VI standard errors are clustered by countries. All regressions are estimated by probit and marginal effects are reported.

Table 11: Real Exchange Rate and Export Surges, Tobit Regressions

\begin{tabular}{|c|c|c|c|c|c|c|}
\hline & $\mathbf{I}$ & II & III & IV & $\mathbf{V}$ & VI \\
\hline & \multicolumn{2}{|c|}{ Merchandise } & \multicolumn{2}{|c|}{$\begin{array}{c}\text { Traditional } \\
\text { Services }\end{array}$} & \multicolumn{2}{|c|}{ Modern Services } \\
\hline \multirow[t]{2}{*}{ RER, Average } & $0.63 * * *$ & $0.77 * * *$ & $0.83 * * *$ & $0.81 * *$ & $1.24 * * *$ & $1.42 *$ \\
\hline & {$[3.68]$} & [2.97] & {$[4.59]$} & [1.97] & [2.95] & {$[1.76]$} \\
\hline \multirow[t]{2}{*}{ RER*Dummy for Developing Countries } & & -0.18 & & 0.03 & & -0.24 \\
\hline & & {$[0.54]$} & & [0.07] & & {$[0.23]$} \\
\hline \multirow{2}{*}{ Log Per Capita Income, Lag } & 0 & 0 & 0 & 0 & 0.04 & 0.04 \\
\hline & [0.204] & {$[0.21]$} & {$[0.14]$} & {$[0.14]$} & [1.13] & [1.13] \\
\hline Year Fixed Effects & Yes & Yes & Yes & Yes & Yes & Yes \\
\hline Observations & 1964 & 1964 & 1925 & 1925 & 1955 & 1955 \\
\hline Pseudo R-squared & 0.19 & 0.19 & 0.14 & 0.14 & 0.057 & 0.057 \\
\hline
\end{tabular}

Note: $*, * *, * * *$ indicate that coefficients are significant at $10,5,1$ percent levels respectively. Standard errors are clustered by countries. Regressions are estimated using the tobit model and marginal effects are reported. 
Table 12: The Real Exchange Rate, Other Controls and Export Surges, Tobit Regressions

\begin{tabular}{|c|c|c|c|}
\hline & I & II & III \\
\hline & Merchandise & Traditional Services & Modern Services \\
\hline \multirow[t]{2}{*}{ RER, Average } & $0.65 * * *$ & $0.83 * * *$ & $1.27 * *$ \\
\hline & [3.07] & [3.47] & [1.98] \\
\hline \multirow[t]{2}{*}{ Log Per Capita Income, PPP, Lag } & 0 & -0.03 & 0.05 \\
\hline & {$[0.18]$} & [1.61] & [1.20] \\
\hline \multirow[t]{2}{*}{ RER Volatility, Average } & -0.04 & $-0.07 * *$ & $-0.14 * *$ \\
\hline & {$[1.54]$} & {$[2.46]$} & [2.15] \\
\hline \multirow[t]{2}{*}{ Currency Crisis, Lag } & 0.06 & $0.11 * *$ & 0.08 \\
\hline & [0.905] & [2.01] & {$[0.77]$} \\
\hline \multirow[t]{2}{*}{ FDI, Average } & 0.01 & $0.02 * * *$ & -0.01 \\
\hline & {$[1.31]$} & [2.99] & {$[0.38]$} \\
\hline \multirow[t]{2}{*}{ Savings, Average } & 0 & $0.01 * *$ & 0.01 \\
\hline & [1.13] & [2.49] & [1.48] \\
\hline \multirow[t]{2}{*}{ Index, English } & 0 & 0.01 & 0.05 \\
\hline & {$[0.17]$} & {$[0.31]$} & [1.16] \\
\hline Year Fixed Effects & Yes & Yes & Yes \\
\hline Observations & 1495 & 1460 & 1487 \\
\hline Pseudo R-squared & 0.178 & 0.176 & 0.073 \\
\hline
\end{tabular}

Note: *,**,*** indicate that coefficients are significant at 10,5, 1 percent levels respectively. Standard errors are clustered by countries. Regressions are estimated using the tobit model and marginal effects are reported.

\section{Conclusion}

The role of exports in economic growth and, in turn, of the real exchange rate in export promotion, is prominent in the literature on development and globalization. Much of this literature dates, however, from the era when exports meant exports of merchandise, where for an increasing number of countries today, exports increasingly means exports of services. This raises the question, among others, of whether the emphasis in the earlier literature on the importance of a competitively valued exchange rate for promoting exports carries over to this new environment.

To address this question, we have studied the response of exports of both traditional and modern services to changes in the real exchange rate. We analyze both changes in average rates of export growth and episodes marked by sharp surges in exports, and we distinguish developed and developing countries. We find that the exports of services, and especially modern services, respond even more than the exports of merchandise to changes in the real exchange rate. We conjecture that this may reflect that services, and especially modern services, use fewer imported inputs, that these sectors have lower fixed costs of entry, making for a more elastic supply response, or that the demand for these exports is more price elastic. 
In contrast, we do not find consistent evidence of differential effects across advanced and developing countries. Nonetheless, as less-advanced countries shift in the course of development from exporting primarily commodities and merchandise to exporting traditional and modern services, these findings suggest that appropriate policies toward the real exchange rate become, if anything, even more important.

This said, relying on an undervalued exchange rate to encourage the growth of exports of services, as of merchandise, has its limitations. To put it another way, limiting the natural tendency for the real exchange rate to appreciate as an economy develops can have costs as well as benefits. Eichengreen (2008) and Haddad and Pancaro (2010) caution that depreciation/undervaluation can be deployed as a policy tool to spur growth only in the short term because a country cannot maintain a depreciated real exchange rate indefinitely. Potential costs include tensions with other countries, accumulation of foreign exchange reserves on which capital losses may occur, and the fact that adjustment, when it occurs, may come in the form of inflation. For a competitive real exchange rate to succeed in boosting exports it will have to be accompanied by strong institutions, sound macroeconomic policies, a disciplined labor force, high savings rates or other policies conducive to attracting foreign capital. Finally, for the benefits of the policy to exceed the costs, countries using real exchange rate depreciation to jumpstart exports and growth should have an exit strategy in mind and, ideally, in place. 


\section{Appendix A: Data Sources, Summary Statistics and Different Real Exchange Rate Variables}

Table A1 shows that correlation coefficients between different real exchange rate series in levels are numerically not very large and that only some are statistically significant. ${ }^{26}$

Table A1: Correlation Coefficients between Different Exchange Rate Series, levels

\begin{tabular}{lllll}
\hline & Log RER & RER, Residuals & $\begin{array}{l}\text { Log RER, } \\
\text { IFS }\end{array}$ & $\begin{array}{l}\text { Log REER, } \\
\text { IFS }\end{array}$ \\
\hline Log RER & 1 & & \\
Log RER, Residuals & $0.88^{* * *}$ & 1 & & \\
Log RER, IFS & $0.31^{* * *}$ & $0.43^{* * *}$ & 1 & \\
Log REER, IFS & $0.06^{* * *}$ & 0.08 & $0.01^{*}$ & 1 \\
\hline
\end{tabular}

Note: the entry in each case is the correlation coefficient and the value in parentheses is the p value to accept the hypothesis that the correlation coefficient is equal to zero. $*, * *, * * *$ indicate that the coefficient is significantly different from zero at 10,5 and 1 percent level of significance. The correlations have been calculated using the data averaged over five year periods.

The correlations between percent changes in different real exchange rate measures are shown in Table A2, which by comparison, are quite large and also statistically significant at the 1 percent level. The correlation between the two Penn World Table-based measures, one of which adjusts for per capita incomes, is quite high (0.99), suggesting that the adjustment will make relatively little difference to the analysis.

\section{Table A2: Correlation Coefficients between Log Changes in Different Real Exchange Rate Variables}

\begin{tabular}{|c|c|c|c|c|}
\hline & $\begin{array}{l}\text { Log } \\
\text { difference in } \\
\text { RER }\end{array}$ & $\begin{array}{l}\text { Log difference } \\
\text { in RER, } \\
\text { Residuals }\end{array}$ & $\begin{array}{l}\text { Log difference } \\
\text { in RER, IFS }\end{array}$ & $\begin{array}{l}\text { Log } \\
\text { difference in } \\
\text { REER, IFS }\end{array}$ \\
\hline Log difference in RER & 1 & & & \\
\hline $\begin{array}{l}\text { Log difference in RER, } \\
\text { residuals }\end{array}$ & $0.99 * * *$ & 1 & & \\
\hline Log difference in RER, IFS & $0.82 * * *$ & $0.90 * * *$ & 1 & \\
\hline Log difference in REER, IFS & $0.62 * * *$ & $0.60 * * *$ & $0.56 * * *$ & 1 \\
\hline
\end{tabular}

Note: The entry in each case is the correlation coefficient and the value in parentheses is the $p$ value to accept the hypothesis that the correlation coefficient is equal to zero. *, **, *** indicate that the coefficient is significantly different from zero at 10,5 and 1 percent level of significance. The correlations have been calculated using the data averaged over five-year periods.

We include different RER series in the regressions, in Table A3, and find the results to be robust.

\footnotetext{
${ }^{26}$ An increase in the value of the REER series indicates an appreciation, whereas for the other three series an increase in the value indicates a depreciation. In the results that we have reported here, we have flipped the sign of REER to make it consistent with those for the other real exchange rate series.
} 
Table A3: Exports Growth and Different RER Measures

\begin{tabular}{lrrrrrr}
\hline & I & II & III & IV & V & VI \\
\hline & \multicolumn{2}{c}{ Merchandise } & Traditional Services & \multicolumn{2}{r}{ Modern Services } \\
\hline Log Per Capita Income, Lag & -0.04 & -0.06 & $-0.06^{* *}$ & -0.06 & 0.05 & 0.01 \\
& {$[1.36]$} & {$[1.47]$} & {$[2.43]$} & {$[1.15]$} & {$[1.00]$} & {$[0.13]$} \\
Log difference in RER, IFS & $.14^{* * *}$ & & $0.10^{* * *}$ & & $0.19^{* * *}$ & \\
& {$[5.92]$} & & {$[3.78]$} & & {$[3.85]$} & \\
Log difference in REER, IFS & & $.15^{* * *}$ & & $0.16^{* * *}$ & & $0.22 * * *$ \\
& & {$[5.72]$} & & {$[4.17]$} & & {$[4.02]$} \\
\hline Country Fixed Effects & Yes & Yes & Yes & Yes & Yes & Yes \\
Time Fixed Effects & Yes & Yes & Yes & Yes & Yes & Yes \\
Observations & 317 & 225 & 317 & 225 & 317 & 225 \\
Number of countries & 62 & 41 & 62 & 41 & 62 & 41 \\
R-squared (within) & 0.17 & 0.13 & 0.13 & 0.2 & 0.12 & 0.12 \\
\hline
\end{tabular}

Note: The dependent variable is growth in exports of merchandise, traditional and modern services, (in constant USD). Observations are averages over five-year periods. Data are from 1980-2009. Regressions include country fixed effects and period-fixed effect, as indicated. Standard errors are robust and clustered at countries. 
Table A4: Variables and Data Sources

\begin{tabular}{|c|c|}
\hline Variable & Source \\
\hline Merchandise Exports & Calculated using the data at constant USD from the WDI. \\
\hline Modern Services Exports & Calculated using the data at constant USD from the WDI. \\
\hline Traditional Services Exports & Calculated using the data at constant USD from the WDI. \\
\hline \multicolumn{2}{|l|}{ Real Per Capita Income, Log } \\
\hline RER, PPP, Log Difference & $\begin{array}{l}\text { Log difference of real exchange rate in purchasing-power-parity from } \\
\text { Penn World Tables, vis-a-vis the U.S. }\end{array}$ \\
\hline RER, PPP, Residual, Log Difference & $\begin{array}{l}\text { We regress the real exchange rate in PPP on real per-capita GDP and year } \\
\text { fixed effects; and take the difference between the log real exchange rate } \\
\text { at PPP and the log fitted value from the regression. }\end{array}$ \\
\hline RER, IFS, Log difference & $\begin{array}{l}\text { We construct the bilateral real exchange rate vis-a-vis the U.S. using data } \\
\text { from the IMF's International Financial Statistics on nominal exchange } \\
\text { rates vis-a-vis the U.S. dollar and the consumer price index for the US } \\
\text { and other countries. }\end{array}$ \\
\hline RER, PPP, Log difference & $\begin{array}{l}\text { We obtain an estimate of the real effective exchange rate from IFS and } \\
\text { the World Development Indicators of the World Bank, and take its log } \\
\text { difference, but its country coverage is more limited. }\end{array}$ \\
\hline Volatility of Real exchange rate & $\begin{array}{l}\text { Monthly bilateral real exchange rate calculated using data on bilateral } \\
\text { exchange rate and CPI of the U.S. and other countries, and calculate } \\
\text { standard deviation using the monthly data for each country for that year. }\end{array}$ \\
\hline Savings & Gross domestic savings (\% of GDP), from WDI \\
\hline Education & $\begin{array}{l}\text { Average years of schooling in population more than } 25 \text { (or } 15) \text { years of } \\
\text { age, percent of population with completed tertiary (or secondary) } \\
\text { educations in } 25 \text {-plus age groups. All measures are highly correlated, } \\
\text { bivariate correlation being } .65 \text { or higher (from http://www.barrolee.com). }\end{array}$ \\
\hline Tariff & We interpolated the tariff data, and also calculate the decline in tariff. \\
\hline Foreign Direct Investment & $\begin{array}{l}\text { We update the data on stock of FDI inflows in Lane and Milesi-Ferreti } \\
\text { using the IFS data for 2008, } 2009 \text { and } 2010 \text {. We have calculated the FDI } \\
\text { inflow stock with GDP ratio, but it is available only until } 2007 .\end{array}$ \\
\hline English Language & $\begin{array}{l}\text { We create an index which takes a value } 3 \text { if English is the first official or } \\
\text { spoken language, } 2 \text { if English is the second spoken or official language, } 1 \\
\text { if it is third official or most spoken language, } 0 \text { if is not one of the top } \\
\text { three official languages or one of the three most spoken languages. }\end{array}$ \\
\hline Date of Joining WTO & $\begin{array}{l}\text { Dummy takes a value } 0 \text { before a country became a member and } 1 \\
\text { thereafter. From WTO's website: } \\
\text { http://www.wto.org/english/thewto_e/whatis_e/tif_e/org6_e.htm }\end{array}$ \\
\hline Income Groups & $\begin{array}{l}\text { Based on the data sheet given by World Bank last updated in April 2012: } \\
\text { low income, } \$ 1,005 \text { or less; lower middle income, } \$ 1,006-3,975 ; \text { upper } \\
\text { middle income, } \$ 3,976-12,275 \text {; high income, } \$ 12,276 \text { or more. Income } \\
\text { classifications set on } 1 \text { July } 2011 \text { remain in effect until } 1 \text { July } 2012 \text {. }\end{array}$ \\
\hline Currency crisis & $\begin{array}{l}\text { Data on currency crisis is from Leaven et al for the countries that they } \\
\text { have covered. For Australia, Austria, Bahrain, Denmark, France, } \\
\text { Germany, Ireland, Mauritius, Netherlands and Switzerland we take the } \\
\text { crisis dates from Reinhart and Rogoff. }\end{array}$ \\
\hline
\end{tabular}


TableA5: Summary Statistics

\begin{tabular}{lrrrrr}
\hline Variable & Observations & Mean & $\begin{array}{r}\text { Std. } \\
\text { Dev. }\end{array}$ & Min & Max \\
\hline Growth of Merchandise Exports & 380 & 0.06 & 0.08 & -0.24 & 0.70 \\
Growth of Services Exports & 380 & 0.06 & 0.07 & -0.19 & 0.45 \\
Growth of Modern Services Exports & 380 & 0.08 & 0.12 & -0.31 & 0.79 \\
Growth of Traditional Services Exports & 380 & 0.06 & 0.08 & -0.30 & 0.58 \\
Real Per Capita Income, Log & 380 & 8.68 & 1.18 & 5.99 & 10.73 \\
RER, Log Difference & 380 & -0.02 & 0.18 & -0.57 & 0.99 \\
Savings/GDP & 380 & 18.65 & 9.32 & -10.52 & 50.82 \\
Net FDI/GDP & 378 & 1.99 & 2.09 & -0.19 & 15.53 \\
Year of Schooling & 366 & 6.65 & 3.00 & 0.37 & 13.23 \\
Internet Penetration & 258 & 13.98 & 21.77 & 0.00 & 88.03 \\
Currency Crisis & 337 & 0.88 & 0.22 & 0 & 1 \\
Volatility of RER & 308 & 0.77 & 0.67 & -0.97 & 3.94 \\
Financial Reform Index & 347 & 0.60 & 0.28 & 0 & 1 \\
English, Index & 380 & 0.67 & 1.15 & 0 & 3 \\
Tariff & 257 & 15.5 & 12.8 & 0 & 96.9 \\
\hline
\end{tabular}

Note: The summary statistics are for five-year averages that have been used in the regressions for export volumes. 


\section{Appendix B. Sensitivity Analysis}

In this appendix we provide further analysis of the additional covariates of service exports analyzed in Section 3.

Table B1: Growth of Merchandise Exports, (All Countries), RER and Other Controls

\begin{tabular}{lcccccc}
\hline & $\mathrm{I}$ & $\mathrm{II}$ & $\mathrm{III}$ & $\mathrm{IV}$ & $\mathrm{V}$ & $\mathrm{VI}$ \\
\hline Log Per Capita Income, Lag & -0.03 & -0.02 & -0.04 & $-0.01^{* *}$ & $-0.06^{* *}$ & $-0.01^{*}$ \\
& {$[1.16]$} & {$[1.00]$} & {$[1.57]$} & {$[1.96]$} & {$[2.37]$} & {$[1.70]$} \\
RER & $0.15^{* * * *}$ & $0.15^{* * *}$ & $0.13^{* * *}$ & $0.15^{* * *}$ & $0.16^{* * * *}$ & $0.16^{* * *}$ \\
& {$[4.28]$} & {$[4.28]$} & {$[3.37]$} & {$[4.73]$} & {$[4.11]$} & {$[4.23]$} \\
Savings (\% of gdp) & 0 & & & & & 0 \\
& {$[0.45]$} & & & & & {$[1.43]$} \\
net FDI (\% of GDP) & & 0 & & & & 0 \\
& & {$[0.26]$} & & & & {$[1.28]$} \\
Currency Crisis & & & $0.25^{* * *}$ & & & 0.04 \\
& & & {$[3.75]$} & & & {$[1.38]$} \\
Index for Proficiency in English & & & & 0 & & -0.01 \\
& & & & {$[1.28]$} & & {$[1.17]$} \\
Volatility of RER (log) & & & & & 0.01 & 0 \\
& Yes & Yes & Yes & Yes & Yes & Yes \\
Country Fixed Effects & Yes & Yes & Yes & Yes & Yes & Yes \\
Time Fixed Effects & 380 & 378 & 337 & 380 & 308 & 274 \\
Observations & 66 & 66 & 65 & 66 & 60 & 55 \\
Number of Countries & 0.15 & 0.15 & 0.19 & & 0.19 & \\
R-squared (within) & & & & & & \\
\hline
\end{tabular}

Note: $*, * *, * * *$ indicate that coefficients are significant at 10,5 , and 1 percent levels respectively. All regressions include robust standard errors 


\begin{tabular}{lcccccc}
\hline & I & II & III & IV & V & VI \\
\hline Log Per Capita Income, Lag & -0.04 & -0.02 & $-0.06^{* *}$ & $-0.01^{* * *}$ & $-0.10^{* * * *}$ & $-0.02^{* * *}$ \\
& {$[1.50]$} & {$[1.11]$} & {$[2.23]$} & {$[3.25]$} & {$[3.95]$} & {$[3.33]$} \\
RER & $0.14^{* * *}$ & $0.14^{* * *}$ & $0.13^{* * *}$ & $0.13^{* * *}$ & $0.12^{* * * *}$ & $0.11^{* * *}$ \\
& {$[4.79]$} & {$[5.07]$} & {$[4.22]$} & {$[4.68]$} & {$[4.09]$} & {$[3.64]$} \\
Savings (\% of gdp) & 0 & & & & & 0 \\
& {$[0.82]$} & & & & & {$[1.42]$} \\
net FDI (\% of GDP) & & $0.01^{* * *}$ & & & & $0.01^{* * *}$ \\
& & {$[3.19]$} & & & & {$[3.19]$} \\
Currency Crisis & & & $0.23^{* *}$ & & & $0.07 * * *$ \\
& & & {$[2.56]$} & & & {$[3.04]$} \\
Index for Proficiency in English & & & & 0 & & 0 \\
& & & & {$[0.31]$} & & {$[0.66]$} \\
Volatility of RER (log) & & & & & $0.03 * * *$ & $0.01 *$ \\
& Yes & Yes & Yes & Yes & Yes & Yes \\
\hline Country Fixed Effects & Yes & Yes & Yes & Yes & Yes & Yes \\
Time Fixed Effects & 380 & 378 & 337 & 380 & 308 & 274 \\
Observations & 66 & 66 & 65 & 66 & 60 & 55 \\
Number of Countries & 0.18 & 0.19 & 0.21 & & 0.23 & \\
R-squared (within) & & & & & \\
\hline Nin & & & & & & \\
\hline
\end{tabular}

Note: $* * *, * * *$ indicate that coefficients are significant at 10,5 , and 1 percent levels respectively. All regressions include robust standard errors 


\begin{tabular}{lcccccc}
\hline & I & II & III & IV & V & VI \\
\hline Log Per Capita Income, Lag & 0.02 & 0.03 & -0.01 & 0 & 0 & -0.01 \\
& {$[0.29]$} & {$[0.57]$} & {$[0.16]$} & {$[1.01]$} & {$[0.07]$} & {$[1.14]$} \\
RER & $0.23^{* * *}$ & $0.23^{* * *}$ & $0.20^{* * *}$ & $0.23^{* * *}$ & $0.23^{* * *}$ & $0.23^{* * *}$ \\
& {$[3.92]$} & {$[4.00]$} & {$[3.40]$} & {$[4.29]$} & {$[3.48]$} & {$[3.46]$} \\
Savings (\% of gdp) & 0 & & & & & 0 \\
& {$[0.32]$} & & & & & {$[0.75]$} \\
net FDI (\% of GDP) & & $0.01^{*}$ & & & & 0 \\
& & {$[1.72]$} & & & & {$[1.38]$} \\
Currency Crisis & & & $0.24^{* *}$ & & & 0.06 \\
& & & {$[2.35]$} & & & {$[1.63]$} \\
Index for Proficiency in English & & & & $0.01 *$ & & 0.01 \\
& & & & {$[1.66]$} & & {$[1.58]$} \\
Volatility of RER (log) & & & & & 0.02 & 0.01 \\
& & & & & {$[1.50]$} & {$[1.06]$} \\
\hline Country Fixed Effects & Yes & Yes & Yes & Yes & Yes & Yes \\
Time Fixed Effects & Yes & Yes & Yes & Yes & Yes & Yes \\
Observations & 380 & 378 & 337 & 380 & 308 & 274 \\
Number of Countries & 66 & 66 & 65 & 66 & 60 & 55 \\
R-squared (within) & 0.13 & 0.15 & 0.16 & & 0.15 & \\
\hline
\end{tabular}

Note: ***,*** indicate that coefficients are significant at 10,5 , and 1 percent levels respectively. All regressions include robust standard errors 


\section{Appendix C: Identifying Export Surges}

Table C1: Surges in Merchandise, Traditional Services and Modern Services Exports

\begin{tabular}{|c|c|c|c|c|}
\hline Country & $\begin{array}{c}\text { Data } \\
\text { Availability }\end{array}$ & Surge in Merchandise & $\begin{array}{c}\text { Surge in Traditional } \\
\text { Services }\end{array}$ & $\begin{array}{l}\text { Surge in Modern } \\
\text { Services }\end{array}$ \\
\hline Argentina & $1980-2010$ & 1994-1997 & 1995-1998; 2003-2007 & $2000-2007$ \\
\hline Australia & $1980-2010$ & $\begin{array}{l}1993-1996 ; 1999- \\
2001 ; 2005-2008\end{array}$ & 1986-1988; 1993-1996 & $1996-2000$ \\
\hline Austria & $1980-2010$ & $1995-2000 ; 2004-2007$ & 1987-1991; 2004-2008 & $1998-2001 ; 2005-2008$ \\
\hline Bangladesh & $1980-2010$ & 1992-2000; 2003-2006 & 1995-1997 & $1989-1995 ; 2002-2008$ \\
\hline Bolivia & $1980-2010$ & $2000-2006$ & $1985-1987 ; 2002-2005$ & No surges identified \\
\hline Brazil & $1980-2010$ & 1999-2004 & $1998-2004$ & $1996-2002$ \\
\hline Canada & $1980-2010$ & $1993-2000$ & $1994-2000$ & $1983-1988 ; 1996-2000$ \\
\hline Chile & $1980-2010$ & 1985-1989; 1999-2006 & $\begin{array}{l}\text { 1984-1986; 1989- } \\
\text { 1993; 1996-2003 } \\
\end{array}$ & $2000-2003$ \\
\hline China & $1983-2010$ & 1990-1994; 2002-2007 & $\begin{array}{l}1986-1988 ; 1992- \\
1994 ; 1999-2002\end{array}$ & $\begin{array}{l}1984-1987 ; 1989- \\
1993 ; 2002-2008\end{array}$ \\
\hline Colombia & $1980-2010$ & $2003-2006$ & $1985-1988$ & 1984-1990; 2003-2006 \\
\hline Comoros & 1981-1995 & No surges identified & 1992-1995 & 1984-1988 \\
\hline Costa Rica & $1980-2010$ & 1995-1999; 2002-2007 & 1990-1994; 1988-1999 & $\begin{array}{l}\text { 1987-1994; 1998- } \\
\text { 2001; 2005-2008 }\end{array}$ \\
\hline Cote d'Ivoire & 1980-2010 & 1994-1997 & No surges identified & $1990-1994$ \\
\hline Denmark & $1982-2004$ & 1980-1985; 1994-1997 & 1988-1991; 1997-2000 & $1998-2001$ \\
\hline $\begin{array}{l}\text { Dominican } \\
\text { Republic }\end{array}$ & 1980-2010 & $1997-2000$ & 1996-1999 & No surges identified \\
\hline Ecuador & $1980-2010$ & 2004-2008 & 1985-1989; 1998-2000 & 1989-1992 \\
\hline Egypt & $1980-2010$ & 1987-1991; 1999-2006 & 1990-1992; 2003-2005 & No surges identified \\
\hline El Salvador & $1980-2010$ & No surges identified & 1984-1988; 2002-2004 & 1984-1987 \\
\hline Finland & $1980-2010$ & 1992-1998; 2004-2007 & 1992-1994 & 1992-1996; 1999-2002 \\
\hline France & $1980-2010$ & $1994-2000$ & 1988-1992 & No surges identified \\
\hline Germany & 1980-2010 & 1995-2001; 2004-2008 & $\begin{array}{c}\text { 1989-1991;1997-2002; } \\
\text { 2005-2008 }\end{array}$ & $2000-2008$ \\
\hline Greece & 1980-1997 & No surges identified & No surges identified & $1987-1991$ \\
\hline Guatemala & $1980-2010$ & $1997-2000$ & 1987-1990; 1998-2001 & $1985-1992$ \\
\hline Honduras & $1980-2010$ & 1993-1997 & $\begin{array}{l}\text { 1988-1991; 1996- } \\
\text { 1999; 2002-2006 }\end{array}$ & 1986-1989 \\
\hline Hungary & $1983-2010$ & 1995-2000; 2004-2007 & $1985-1987 ; 1994-1997$ & $2000-2007$ \\
\hline India & 1980-2010 & 1987-1992; 2000-2006 & 1986-1992; 2003-2008 & $1994-2000 ; 2003-2006$ \\
\hline Indonesia & $1982-2010$ & 1989-1992 & 1985-1998 & $2002-2005$ \\
\hline Ireland & $1980-2010$ & 1993-1998 & 1994-1998; 2001-2004 & 1987-1992; 1996-2001 \\
\hline Israel & $1980-2010$ & 1997-2000; 2003-2007 & $2003-2005$ & 1996-2000; 2003-2006 \\
\hline Italy & $1980-2010$ & No surges identified & $1992-1995$ & No surges identified \\
\hline Jamaica & $1980-2010$ & 1988-1992 & 1983-1985; 1990-1992 & 1991-1994 \\
\hline
\end{tabular}




\begin{tabular}{|c|c|c|c|c|}
\hline Jordan & $1980-2010$ & $2001-2004$ & $2005-2008$ & $1987-1991 ; 2004-2008$ \\
\hline Kenya & $1980-2010$ & No surges identified & 1985-1990; 2004-2007 & $2004-2008$ \\
\hline $\begin{array}{l}\text { Korea, } \\
\text { Republic of }\end{array}$ & $1980-2010$ & 1994-1998 & 1993-1995 & 1993-1998; 2004-2009 \\
\hline Madagascar & $1980-2005$ & No surges identified & $1986-1989 ; 1997-2000$ & $1985-1991$ \\
\hline Malaysia & $1980-2010$ & 1987-1995; 2003-2006 & $\begin{array}{l}\text { 1985-1996; 1999- } \\
\text { 2001; 2005-2007 }\end{array}$ & 1989-1997 \\
\hline Mali & 1980-2009 & No surges identified & $1999-2001$ & $2004-2007$ \\
\hline Mauritius & $1980-2010$ & 1984-1987 & $\begin{array}{l}\text { 1986-1990; 1994- } \\
2001 ; 2004-2007\end{array}$ & $1986-1989 ; 2007-2010$ \\
\hline Mexico & $1980-2010$ & $1994-2000$ & No surges identified & 1984-1987 \\
\hline Morocco & $1980-2010$ & $2005-2008$ & $\begin{array}{l}1982-1985 ; 1999- \\
2001 ; 2004-2007\end{array}$ & $1982-1985 ; 2001-2007$ \\
\hline Mozambique & $1981-2010$ & 1999-2006 & 1987-1990; 2005-2010 & 1991-1995 \\
\hline Nepal & $1980-2010$ & $1997-2000$ & 1991-1994 & 1994-1997 \\
\hline Netherlands & $1980-2010$ & 1994-1998; 2005-2008 & No surges identified & $1997-2000$ \\
\hline New Zealand & 1980-2009 & No surges identified & 1991-1995 & 1980-1983; 1998-2001 \\
\hline Norway & $1980-2010$ & 1994-1997 & 1989-1991 & 1996-2000; 2004-2007 \\
\hline Pakistan & $1980-2010$ & 1985-1992; 2002-2005 & No surges identified & 1983-1987; 1993-1996 \\
\hline Paraguay & $1980-2010$ & 1984-1990; 2002-2008 & No surges identified & $1997-2000$ \\
\hline Peru & $1980-2010$ & 1994-1997; 2004-2008 & 1996-1998; 2004-2008 & No surges identified \\
\hline Philippines & $1980-2010$ & 1987-1991; 1993-2000 & 1991-1993 & 1994-1997; 2003-2010 \\
\hline Portugal & $1980-2010$ & $\begin{array}{c}\text { 1982-1985; } 1987-1990 ; \\
1994-1997\end{array}$ & 1984-1985; 2006-2008 & $2005-2008$ \\
\hline Senegal & 1980-2009 & No surges identified & No surges identified & No surges identified \\
\hline South Africa & $1980-2010$ & $2005-2008$ & 1994-1998; 2001-2003 & $2005-2008$ \\
\hline Spain & $1980-2010$ & 1993-1997 & 1981-1984; 1994-2000 & $1993-2001 ; 2005-2008$ \\
\hline Sri Lanka & $1980-2010$ & 1992-1996 & 1989-1995 & No surges identified \\
\hline Swaziland & $1980-2010$ & $2000-2003$ & 1986-1989 & No surges identified \\
\hline Sweden & $1980-2010$ & No surges identified & 1999-2001; 2004-2008 & $1997-2001$ \\
\hline Switzerland & $1981-2010$ & 2004-2008 & 1997-2000; 2005-2007 & $1997-2000 ; 2004-2010$ \\
\hline Thailand & $1980-2010$ & 1986-1989; 2003-2006 & 1984-1990; 1999-2002 & 1988-1993 \\
\hline Togo & $1980-2010$ & No surges identified & No surges identified & No surges identified \\
\hline Tunisia & $1980-2010$ & 1988-1991; 2004-2008 & $2004-2008$ & $1998-2001 ; 2007-2010$ \\
\hline
\end{tabular}

Note: We dropped several countries because either there was no data available or because the data was available only for a few years and was not sufficient to determine structural breaks. These include Belarus, Belgium, Burundi, Cape Verde, Croatia, Czech Republic, Estonia, Iran, Laos, Latvia, Lebanon, Lithuania, Namibia, Poland, Slovenia, Tanzania and Uganda. In addition, only partial data was available for Burkina Faso, Central African Republic, Japan, Malawi, Mauritania, Rwanda and Zimbabwe. Of the countries we have included in the analysis, we have full data for five-year panels for all countries except Brazil, Comoros, Denmark, Hungary, Indonesia, Mozambique and Swaziland. 
Figures C2, C3 and C4 show selected episodes of surges in exports of merchandise, modern services and traditional services.

Figure C2: India-Surge in Exports of Goods (1987-1992 and 2000-2006)

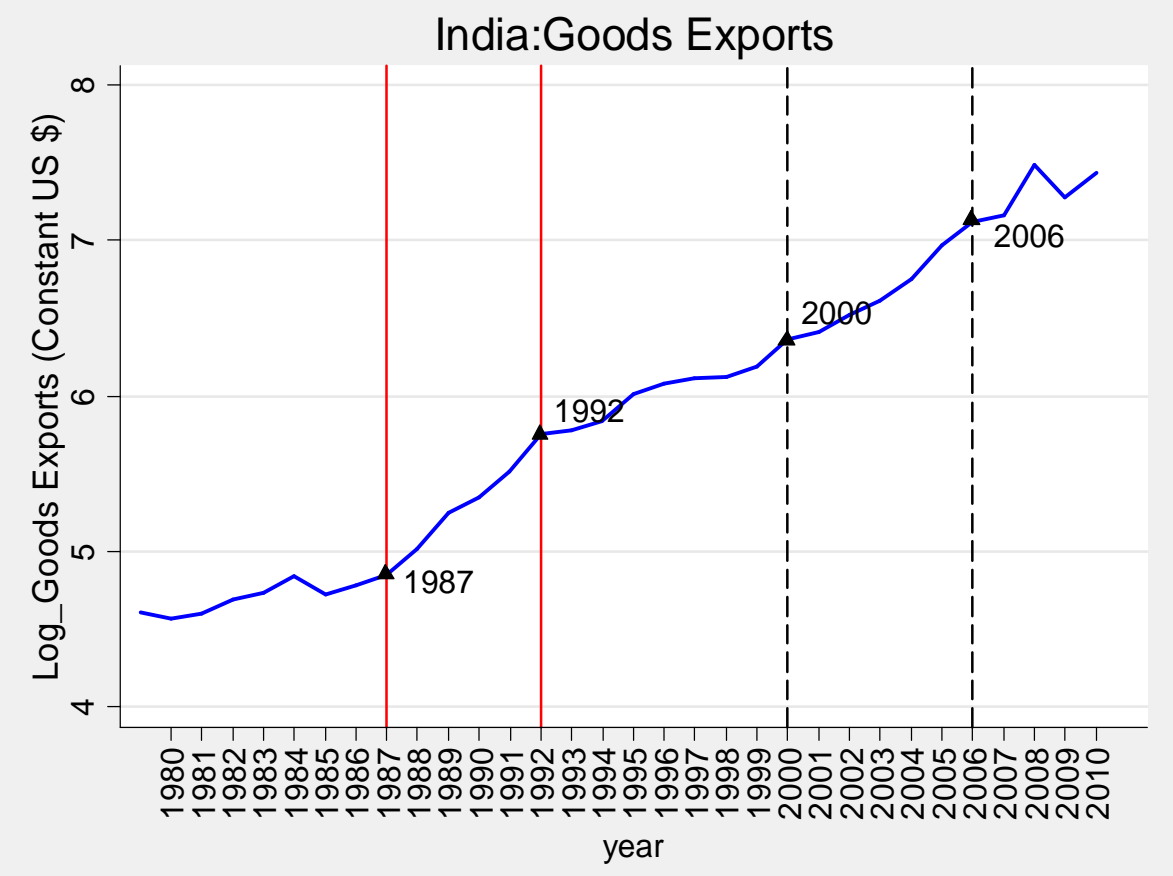

Figure C3: India-Surge in Exports of Traditional Services (1986-1992 and 2003-2008)

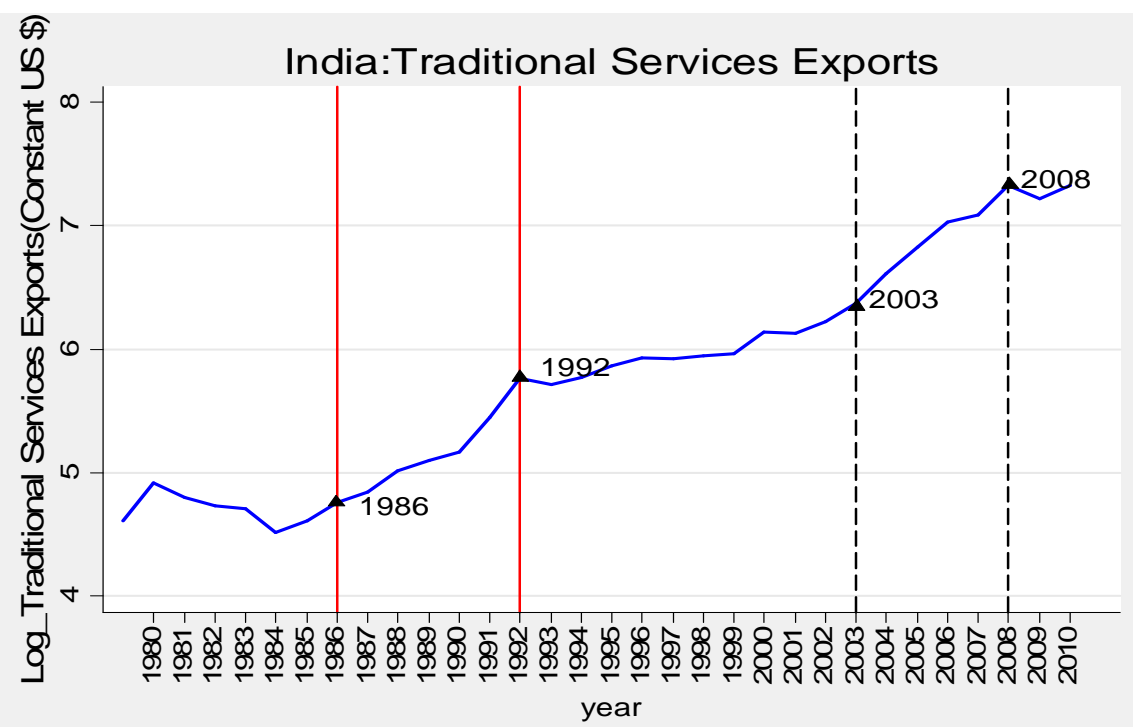


Figure C4: India —Surge in Exports of Modern Services (1994-2000 and 2003-2006)

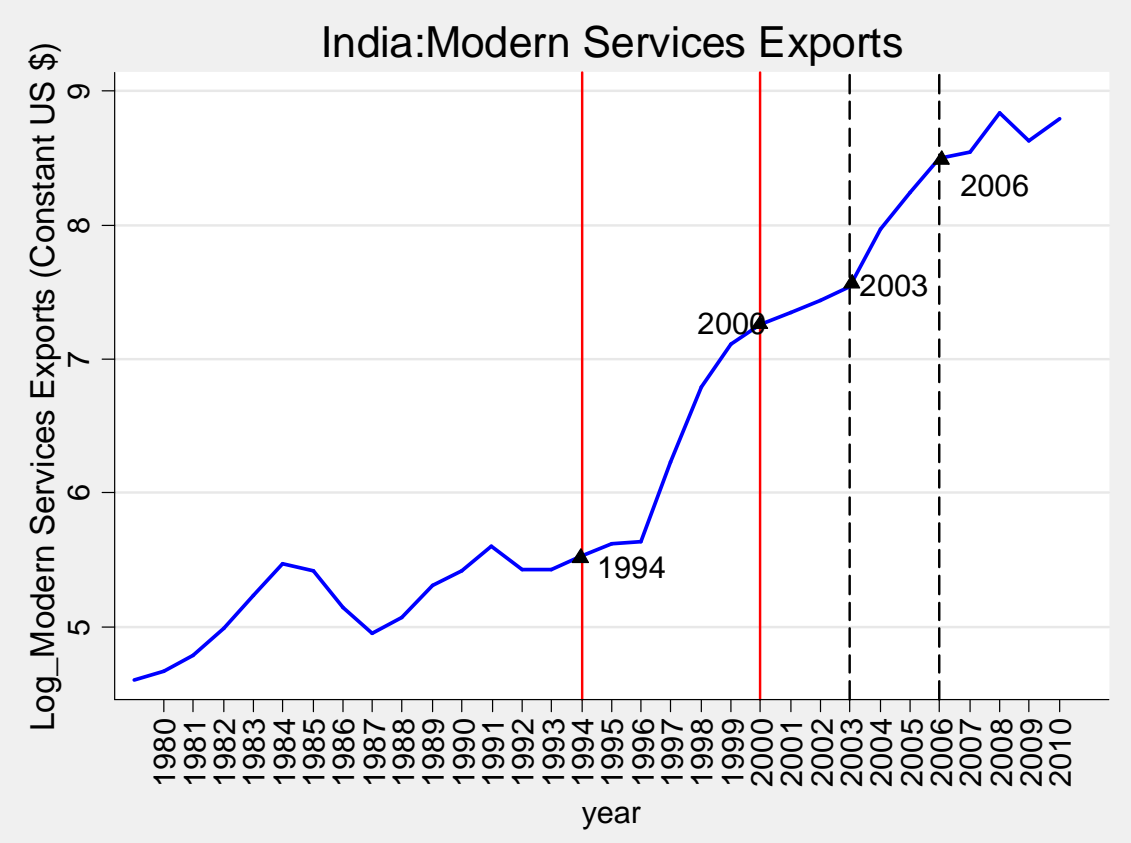




\section{Appendix D: Characterizing Export Surges}

Figure D1: Temporal Distribution of the Episode of Export Surge in Merchandise

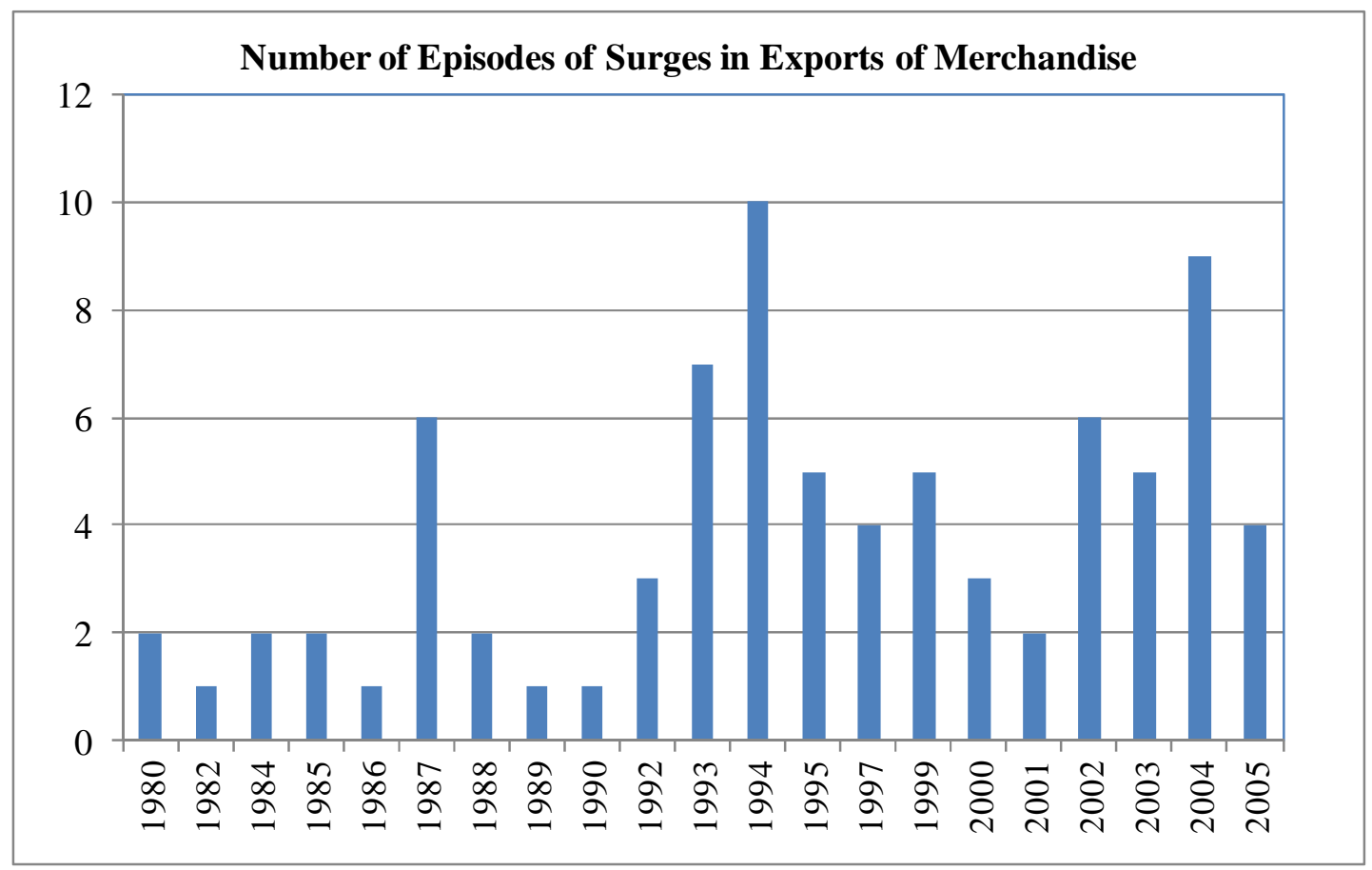


Figure D2: Temporal Distribution of Export Surges in Modern Services

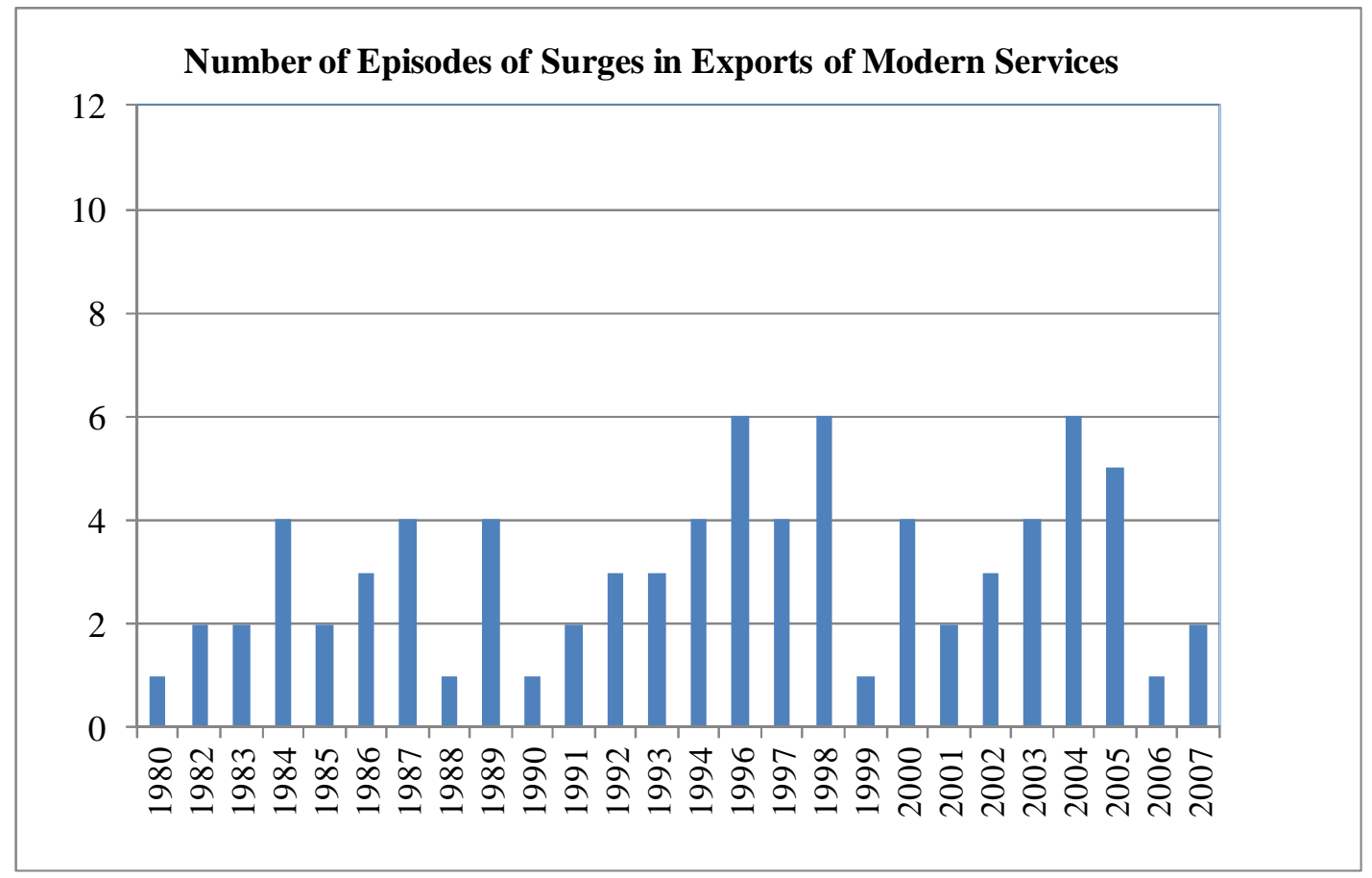

Figure D 3: Temporal Distribution of Export Surges in Traditional Services

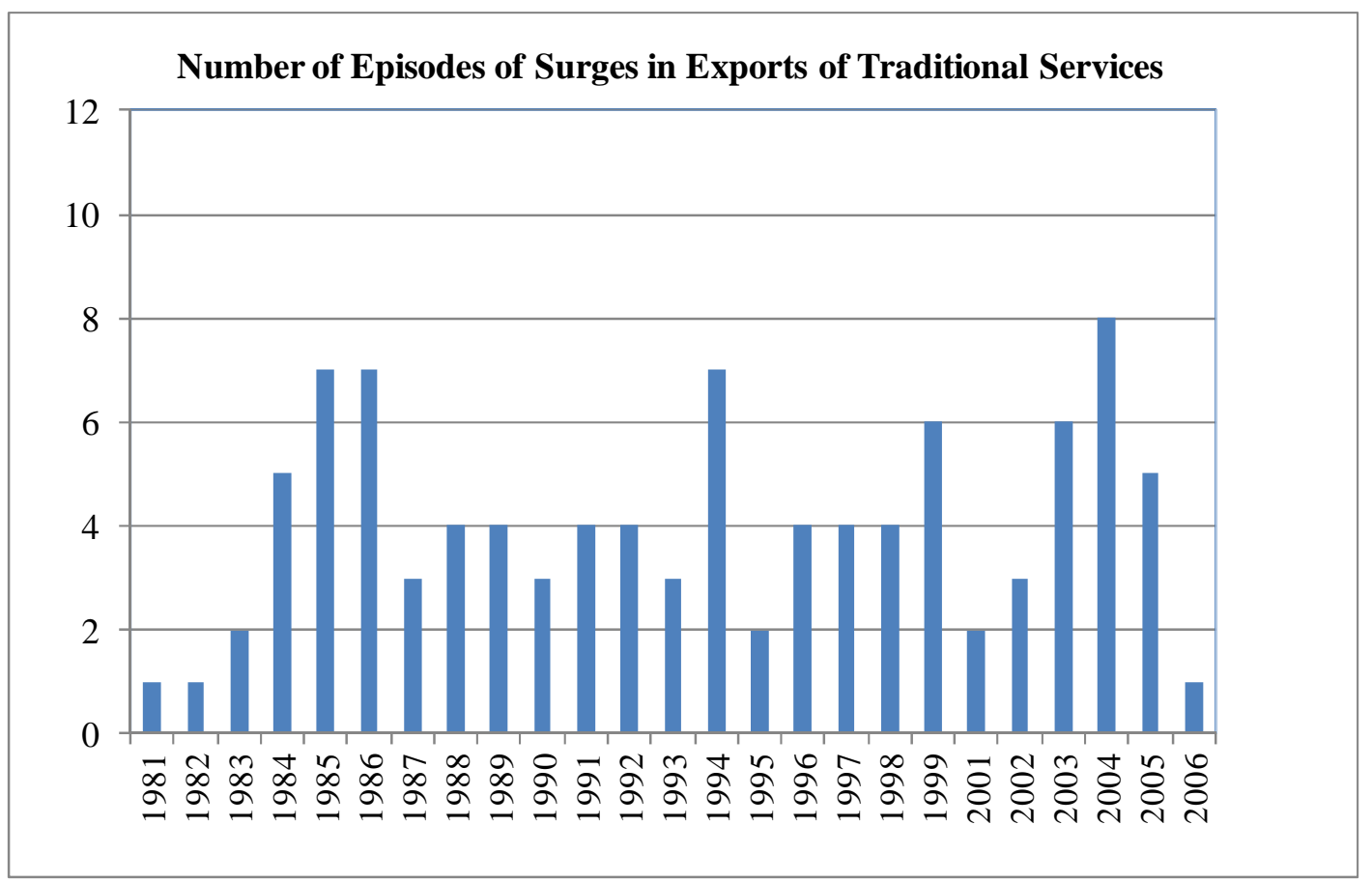




\section{Appendix E: Predicting Export Surges}

The financial reform index in Figure E1 shows a trend toward liberalization of the financial sector prior to surges of exports of services and especially fast liberalization prior to surges in exports of modern services by developing countries. Export surges also seem to be preceded by an increase in savings rate, especially in developing countries (Figure E2). Surges in exports of modern services, especially in developed countries, are accompanied by and preceded by a sharp increase in internet penetration (Figure E3).

Figure E1: Financial Reforms and Export Surges in Services (Traditional and Modern)

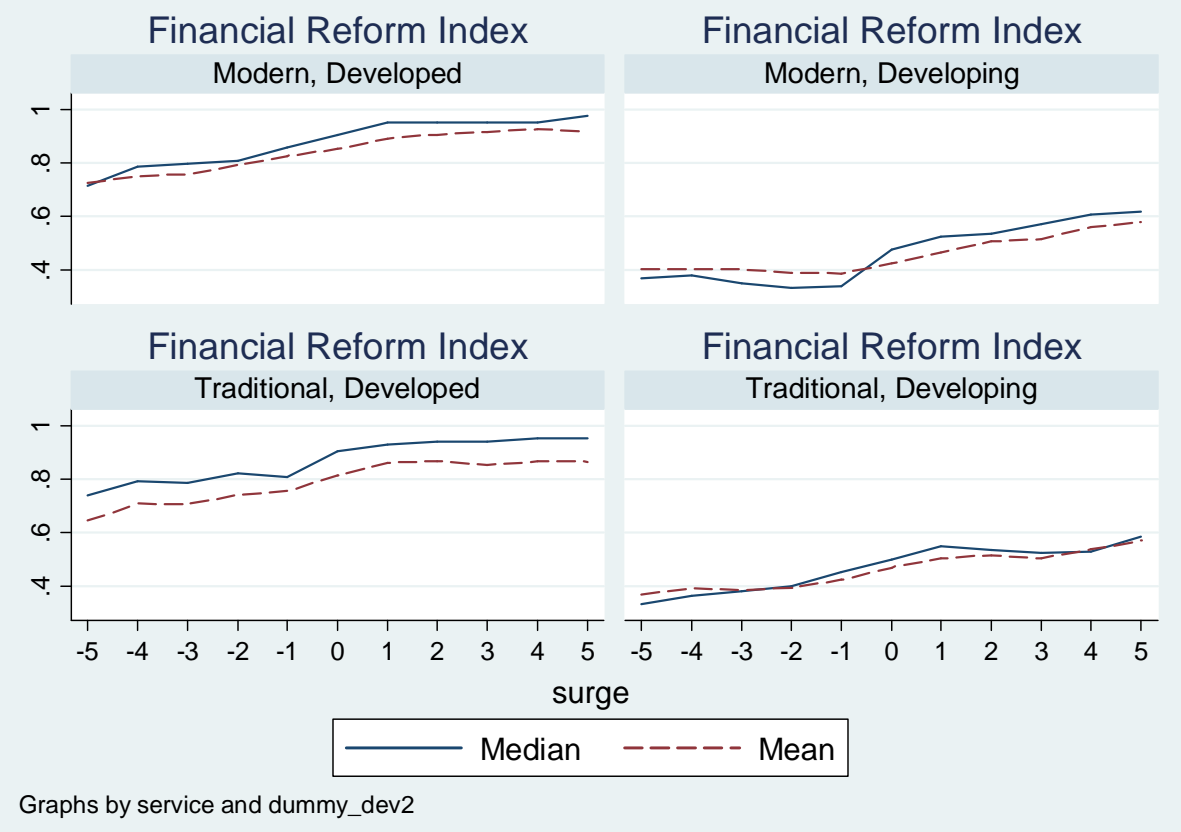


Figure E2: Savings and Export Surges in Services (Traditional and Modern)

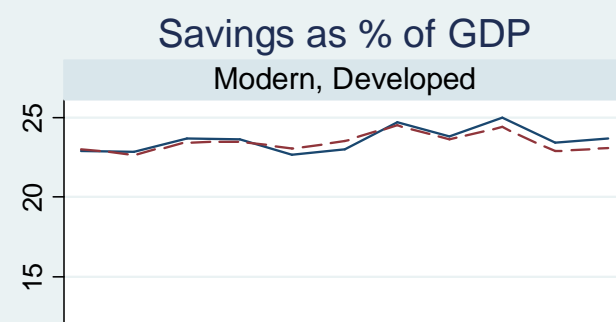

Savings as \% of GDP

Traditional, Developed

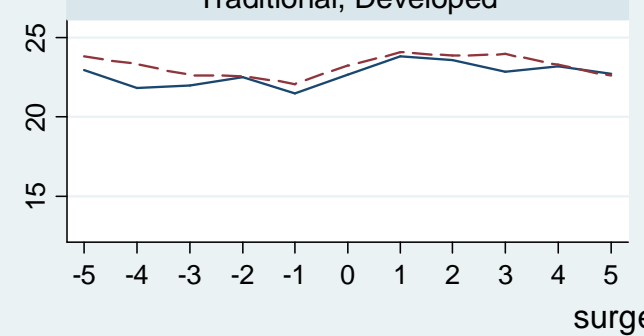

surge
Savings as \% of GDP

Modern, Developing

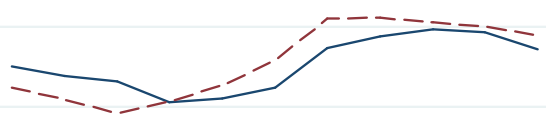

Savings as $\%$ of GDP Traditional, Developing

$$
\text { Median ----- Mean }
$$

Graphs by service and dummy_dev2

\section{Figure E3: Surges in Exports of Traditional and Modern Services and Internet Penetration}

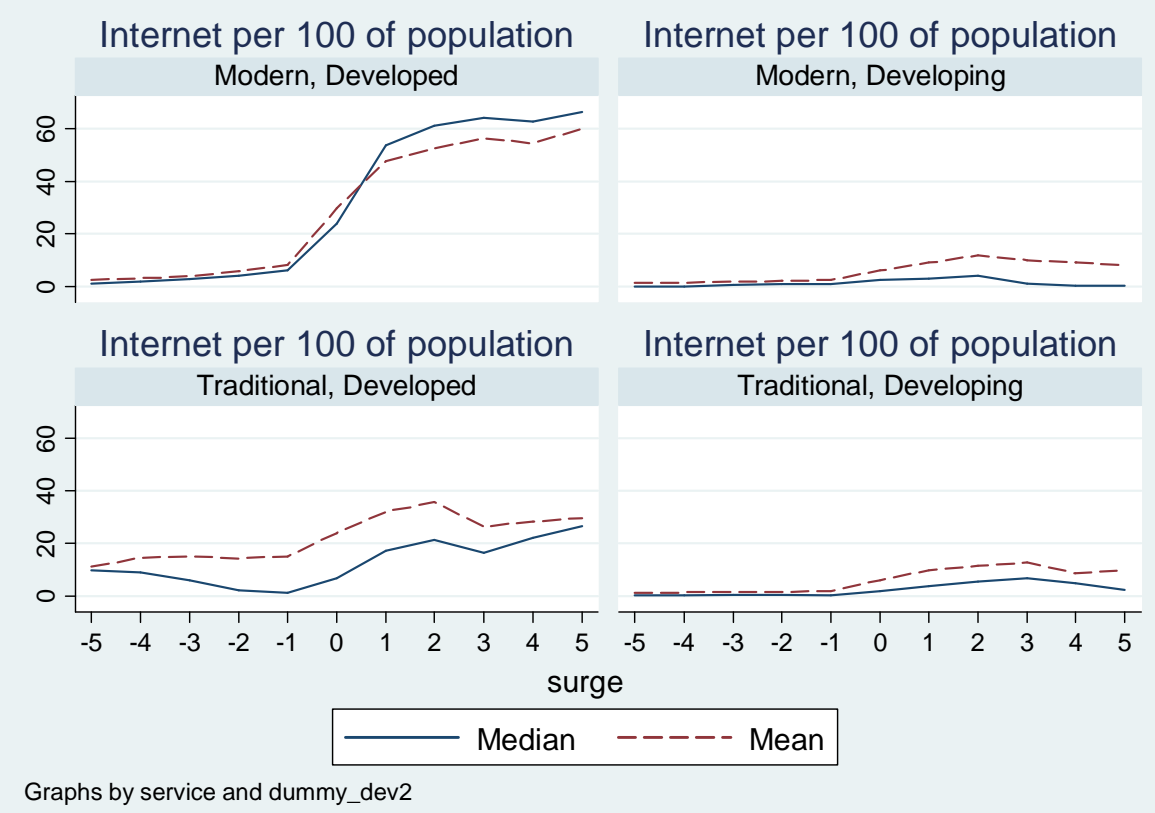


In Tables E1-E3, we estimate regressions to predict export surges in merchandise, traditional services and modern services respectively. In column 1 we estimate a probit regression and cluster the standard errors by countries. In column II we estimate a linear probability model, in which we also include country fixed effects. In column III we estimate a random effect probit model, and in column IV a random effect logit model (in the last two columns we do not report the marginal effects).

Table E1: Surges in Merchandise and RER

\begin{tabular}{lrrrr}
\hline & I & II & III & IV \\
\hline RER, Average & $0.77 * * *$ & $0.90^{* * *}$ & $4.36 * * *$ & $7.66 * * *$ \\
& {$[3.35]$} & {$[2.74]$} & {$[3.59]$} & {$[3.65]$} \\
RER, Average*Developing Countries & & -0.38 & -1.8 & -3.33 \\
& & {$[0.98]$} & {$[1.38]$} & {$[1.48]$} \\
Log per Capita Income, Lag & 0.02 & $-0.21 * *$ & 0.04 & 0.08 \\
& {$[1.18]$} & {$[2.35]$} & {$[0.55]$} & {$[0.64]$} \\
\hline Country Fixed Effects & Yes & Yes & No & No \\
Year Fixed Effects & Yes & Yes & Yes & Yes \\
Observations & 1847 & 1964 & 1964 & 1964 \\
R-squared & & 0.143 & & \\
Pseudo R-squared & 0.114 & & & \\
\hline
\end{tabular}

Note: *,**,*** indicate that coefficients are significant at 10, 5 and 1 percent levels respectively. All regressions include robust standard errors.

Table E2: Surges in Traditional Services and RER

\begin{tabular}{lrrrr}
\hline & I & II & III & IV \\
\hline RER, Average & $1.12^{* *}$ & $1.18^{* *}$ & $4.35^{* * *}$ & $7.91^{* * *}$ \\
& {$[2.29]$} & {$[2.25]$} & {$[3.97]$} & {$[4.13]$} \\
RER, Average*Developing Countries & -0.09 & -0.16 & -0.21 & -0.68 \\
& {$[0.18]$} & {$[0.31]$} & {$[0.18]$} & {$[0.33]$} \\
Log per capita income, Lag & 0.01 & -0.09 & 0.04 & 0.08 \\
& {$[0.90]$} & {$[-0.99]$} & {$[0.64]$} & {$[0.66]$} \\
\hline Country Fixed Effects & Yes & Yes & No & No \\
Year Fixed Effects & Yes & Yes & Yes & Yes \\
Observations & 1867 & 1925 & 1925 & 1925 \\
R-squared & & 0.099 & & \\
Pseudo R-squared & 0.0914 & & & \\
\hline
\end{tabular}

Note: $* * *, * * *$ indicate that coefficients are significant at 10, 5, and 1 percent levels respectively. All regressions include robust standard errors. 
Table E3: Surges in Modern Services and RER

\begin{tabular}{lrrrr}
\hline & I & II & III & IV \\
\hline RER, Average & $0.68^{* *}$ & $0.86^{* *}$ & $3.17 * * *$ & $6.04 * * *$ \\
& {$[1.98]$} & {$[2.41]$} & {$[2.83]$} & {$[3.15]$} \\
RER, Average*Developing Countries & 0 & -0.24 & -0.27 & -0.75 \\
& {$[0.006]$} & {$[0.59]$} & {$[0.22]$} & {$[0.36]$} \\
Log per capita income, Lag & $0.03^{*}$ & $0.19^{*}$ & $0.18^{* *}$ & $0.32^{* *}$ \\
& {$[1.93]$} & {$[1.74]$} & {$[2.52]$} & {$[2.56]$} \\
\hline Country Fixed Effects & Yes & Yes & No & No \\
Year Fixed Effects & Yes & Yes & Yes & Yes \\
Observations & 1,955 & 1,955 & 1,955 & 1,955 \\
R-squared & & 0.074 & & \\
Pseudo R-squared & 0.076 & & & \\
\hline
\end{tabular}

Note: $* * *, * * *$ indicate that coefficients are significant at 10,5 and 1 percent levels respectively. All regressions include robust standard errors.

In Tables E4-E6 we include other controls in the regressions for export surges in merchandise, traditional services and modern services respectively. Regressions are estimated with probit models and marginal effects are reported.

Results in Table E4 show that among other controls, RER volatility has a negative effect and savings rate has a positive effect on the likelihood of an export surge in merchandise. In column VII, we include all of the controls together, except tariff rate, because it has fewer observations (if we include tariff along with all of the other controls, similar results are obtained).

Table E4: Surges in Merchandise Exports and RER, Including Other Controls

\begin{tabular}{lrrrrrrr}
\hline & I & II & III & IV & V & VI & VII \\
\hline RER, Average & $0.87 * * *$ & $0.73 * * *$ & $0.78^{* * *}$ & $0.78^{* * *}$ & $1.01 * * *$ & $0.77 * * *$ & $0.79 * * *$ \\
& {$[3.35]$} & {$[4.65]$} & {$[5.03]$} & {$[5.07]$} & {$[3.75]$} & {$[5.02]$} & {$[4.19]$} \\
log per capita income, lagged & 0.02 & $0.02 * *$ & $0.02 * *$ & 0.01 & -0.02 & $0.02 * *$ & 0.01 \\
& {$[1.15]$} & {$[2.46]$} & {$[2.49]$} & {$[0.74]$} & {$[-1.23]$} & {$[2.47]$} & {$[0.83]$} \\
RER Volatility, Average & $-0.07 *$ & & & & & $-0.06 * * *$ \\
& {$[-1.83]$} & & & & & {$[-3.20]$} \\
Currency Crisis, Lag & & 0.02 & & & & 0.02 \\
& & {$[0.49]$} & & & & {$[0.40]$} \\
FDI, Average & & & 0 & & & $0.01 *$ \\
& & & {$[0.48]$} & & & {$[1.85]$} \\
Savings, Average & & & $0.00 * * *$ & & $0.00 * *$ \\
Tariff, Average & & & {$[3.14]$} & & {$[2.53]$}
\end{tabular}




\begin{tabular}{lrrrrrrr} 
Index, English & & & & & & 0 & 0.01 \\
& & & & & & {$[0.40]$} & {$[0.56]$} \\
\hline Year Fixed Effects & Yes & Yes & Yes & Yes & Yes & Yes & Yes \\
Observations & 1467 & 1818 & 1819 & 1841 & 964 & 1847 & 1412 \\
R-squared & 0.112 & 0.111 & 0.111 & 0.118 & 0.0622 & 0.114 & 0.111 \\
\hline
\end{tabular}

Note: *, **, *** indicate that coefficients are significant at 10,5 and 1 percent levels respectively. All regressions include robust standard errors.

Results in Table E5 show that RER volatility and higher import tariff both affect the likelihood of an export surge in traditional services negatively where as high FDI, savings rate and wider use of English increases the likelihood of the export surge.

Table E5: Surges in Traditional Services Exports and RER, Including Other Controls

\begin{tabular}{|c|c|c|c|c|c|c|c|}
\hline & I & II & III & IV & $\mathbf{V}$ & VI & VII \\
\hline \multirow[t]{2}{*}{ RER, Average } & $1.26 * * *$ & $0.98 * * *$ & $1.04 * * *$ & $1.06 * * *$ & $1.65 * * *$ & $1.05 * * *$ & $1.07 * * *$ \\
\hline & [4.93] & [6.31] & {$[6.77]$} & [6.79] & [6.21] & {$[6.78]$} & [5.80] \\
\hline \multirow[t]{2}{*}{ Log per Capita Income, lagged } & 0.01 & 0.01 & 0.01 & 0 & 0 & 0.01 & -0.02 \\
\hline & {$[0.53]$} & {$[1.55]$} & {$[0.83]$} & {$[-0.24]$} & {$[-0.19]$} & [1.38] & {$[-1.41]$} \\
\hline \multirow[t]{2}{*}{ RER Volatility, Average } & $-0.10 * * *$ & & & & & & $-0.09 * * *$ \\
\hline & {$[-2.87]$} & & & & & & {$[-4.57]$} \\
\hline \multirow[t]{2}{*}{ Currency Crisis, Lag } & & 0.06 & & & & & $0.10^{*}$ \\
\hline & & {$[1.26]$} & & & & & [1.81] \\
\hline \multirow[t]{2}{*}{ FDI, Average } & & & $0.02 * * *$ & & & & $0.02 * * *$ \\
\hline & & & [4.86] & & & & [3.67] \\
\hline \multirow[t]{2}{*}{ Savings, Average } & & & & $0.00 * * *$ & & & $0.01 * * *$ \\
\hline & & & & [3.65] & & & [4.37] \\
\hline \multirow[t]{2}{*}{ Tariff, Average } & & & & & $-0.00 * *$ & & \\
\hline & & & & & {$[-1.99]$} & & \\
\hline \multirow[t]{2}{*}{ Index, English } & & & & & & $0.01 *$ & 0.01 \\
\hline & & & & & & {$[1.75]$} & [0.81] \\
\hline Year Fixed Effects & Yes & Yes & Yes & Yes & Yes & Yes & Yes \\
\hline Observations & 1,471 & 1,837 & 1,840 & 1,862 & 1,044 & 1,867 & 1,417 \\
\hline R-squared & 0.105 & 0.090 & 0.10 & 0.097 & 0.09 & 0.093 & 0.12 \\
\hline
\end{tabular}

Note: *,**,*** indicate that coefficients are significant at 10, 5 and 1 percent levels respectively. All regressions include robust standard errors. 
Results in Table E6 show that RER volatility has a negative effect and the wider use of English has a positive effect on the likelihood of an export surge in modern services.

Table E 6: Surges in Modern Services and RER, Including Other Controls

\begin{tabular}{|c|c|c|c|c|c|c|c|}
\hline & I & II & III & IV & $\mathrm{V}$ & VI & VII \\
\hline RER, Average & $\begin{array}{r}0.78 * * * \\
{[4.21]}\end{array}$ & $\begin{array}{r}0.72 * * * \\
{[4.84]}\end{array}$ & $\begin{array}{r}0.68 * * * \\
{[4.68]}\end{array}$ & $\begin{array}{r}0.69 * * * \\
{[4.73]}\end{array}$ & $\begin{array}{r}1.08 * * * \\
{[4.48]}\end{array}$ & $\begin{array}{r}0.68 * * * \\
{[4.69]}\end{array}$ & $\begin{array}{r}0.75 * * * \\
{[3.95]}\end{array}$ \\
\hline log per capita income, lagged & $\begin{array}{r}0.04 * * * \\
{[4.03]}\end{array}$ & $\begin{array}{r}0.03 * * * \\
{[3.59]}\end{array}$ & $\begin{array}{r}0.03 * * * \\
{[4.15]}\end{array}$ & $\begin{array}{r}0.02 * * * \\
{[2.65]}\end{array}$ & $\begin{array}{r}0.05 * * * \\
{[4.00]}\end{array}$ & $\begin{array}{r}0.03 * * * \\
{[3.29]}\end{array}$ & $\begin{array}{r}0.04 * * * \\
{[3.16]}\end{array}$ \\
\hline RER Volatility, Average & $\begin{array}{r}-0.07 * * * \\
{[-3.99]}\end{array}$ & & & & & & $\begin{array}{r}-0.06 * * * \\
{[-3.5]}\end{array}$ \\
\hline Currency Crisis, Lag & & $\begin{array}{r}-0.04 \\
{[-0.87]}\end{array}$ & & & & & $\begin{array}{r}0.02 \\
{[0.29]}\end{array}$ \\
\hline FDI, Average & & & $\begin{array}{r}0 \\
{[0.15]}\end{array}$ & & & & $\begin{array}{r}0 \\
{[-0.22]}\end{array}$ \\
\hline Savings, Average & & & & $\begin{array}{r}0 \\
{[1.30]}\end{array}$ & & & $\begin{array}{r}0 \\
{[1.58]}\end{array}$ \\
\hline Tariff, Average & & & & & $\begin{array}{r}0.00 * * \\
{[2.38]}\end{array}$ & & \\
\hline Index, English & & & & & & $\begin{array}{r}0.02 * * * \\
{[3.29]}\end{array}$ & $\begin{array}{r}0.02 * * \\
{[2.31]}\end{array}$ \\
\hline Year Fixed Effects & Yes & Yes & Yes & Yes & Yes & Yes & Yes \\
\hline Observations & 1453 & 1924 & 1927 & 1947 & 1033 & 1955 & 1398 \\
\hline R-squared & 0.062 & 0.078 & 0.076 & 0.076 & 0.066 & 0.081 & 0.068 \\
\hline
\end{tabular}

Note: *,**,*** indicate that coefficients are significant at 10,5 and 1 percent levels respectively. All regressions include robust standard errors. 


\section{References}

Bai, Jushan and Pierre Perron (2003), "Computation and Analysis of Multiple Structural Change Models," Journal of Applied Econometrics 18, pp.1-22.

Berman, Nicolas, Philippe Martin, and Thierry Mayer (2012), "How Do Different Exporters React to Exchange Rate Changes?" Quarterly Journal of Economics 127, pp.437-492.

Borchert, Ingo and Aaditya Mattoo (2009), "The Crises- Resilience of Services Trade”, World Bank, Policy Research Working Paper no. 4917.

Colacelli, Mariana (2008), "Export Responses to Real Exchange Rate Fluctuations: Development Status and Exported Good Effects," unpublished manuscript, Barnard College and Columbia University, New York.

Cheung, Yin-Wong, Menzie D. Chinn, and Eiji Fujii (2009), "The Illusion of Precision and the Role of the Renminbi in Regional Integration," in K. Hamada, B. Reszat and U.Volz (eds.), Towards Monetary and Financial Integration in East Asia, Edward Elgar, Cheltenham, UK.

Eichengreen, Barry (2008), "The Real Exchange Rate and Economic Growth,” Working Paper No. 4, World Bank PREM Network, Commission on Growth and Development.

Eichengreen, Barry and Poonam Gupta (2011), "The Two Waves of Service Sector Growth," Oxford Economic Papers 64, published online December 19, 2011 doi:10.1093/oep/gpr059.

Eichengreen, Barry and Poonam Gupta (2010/2011), "The Service Sector as India's Road to Economic Growth," India Policy Forum 7, National Council of Applied Economic Research (NCAER), New Delhi, and the Brookings Institution, Washington D.C.

Eichengreen, Barry and Poonam Gupta (2012), "Exports of Services: Indian Experience in Perspective," National Institute of Public Finance and Policy (NIPFP) Working Paper No. 102, forthcoming, India Growth and Development Review.

Eilat, Yair and Liran Einav (2004), "The Determinants of International Tourism: A ThreeDimensional Panel Data Analysis," Applied Economics 36, pp.1315-1327.

Feder, Gerschon (1982), “On Exports and Economic Growth," unpublished manuscript, World Bank.

Freund, Caroline and Martha Denisse Pierola (2012), "Export Surges," Journal of Development Economics 97, pp.387-395.

Freund, Caroline and Diana Weinhold (2002), "The Internet and International Trade in Services," American Economic Review 92, pp.236-240. 
Goswami, Arti, Poonam Gupta, Aaditya Mattoo, and Sebastian Saez (2012), "Service Exports: Are the Drivers Different for Developing Countries?" in A. Goswami, A. Mattoo, and S. Saez (eds), Exporting Services: A Developing Country Perspective, Washington, D.C.: The World Bank, pp.25-80.

Goswami, Arti, Aaditya Mattoo, and Sebastian Saez (2012), "Exporting Services: A Developing Country Perspective," in Arti Goswami, Aaditya Mattoo, and Sebastian Saez (eds), Exporting Services: A Developing Country Perspective, Washington, D.C.: The World Bank, pp.1-24.

Gupta, Poonam, Mishra Deepak, and Ratna Sahay (2007), "Behavior of Output during Currency Crises," Journal of International Economics 72(2), pp.428-450.

Jaleel, Ahmad and Andy Kwan (1991), "Causality between Exports and Economic Growth," Economics Letters 37, pp.243-248.

Haddad, Mona and Cosimo Pancaro (2010), "Can Real Exchange Rate Undervaluation Boost Exports and Growth in Developing Countries? Yes, But Not for Long," Economic Premise 20, World Bank PREM Network (June).

Hausmann, Ricardo, Lant Pritchett, and Dani Rodrik (2005) "Growth Accelerations," Journal of Economic Growth 10, pp.303-329.

Johnson, Simon, Jonathan D. Ostry, and Arvind Subramanian (2007), "The Prospects for Sustained Growth in Africa: Benchmarking the Constraints," NBER Working Paper no. 13120.

Kandlikov, Ivan and Thomas Greenes (2010), "The Determinants of Services Exports from Central and Eastern Europe," Economics of Transition 18, pp.763-794.

Rodrik, Dani (2009), “The Real Exchange Rate and Economic Growth,” Brookings Papers on Economic Activity 1, pp.365-412.

Servén, Luis (2003), "Real Exchange Rate Uncertainty and Private Investment in LDCs," Review of Economics and Statistics 85, pp.492-492.

Smith, Mark (2004) "The Impact of the Real Exchange Rate on Export Volumes," Reserve Bank of New Zealand Bulletin 67, pp.5-13.

Tharakan, P.K.M., I. Van Beveren, and T. Van Ourti (2005), "Determinants of India's Software Exports and Goods Exports," Review of Economics and Statistics 87, pp.776-780. 